\title{
Socio-economic factors influencing land-use and land-cover changes in the Miombo woodlands of the Copperbelt province in Zambia
}

\author{
Ferdinand Handavu ${ }^{1,2 *}$, Paxie WC Chirwa ${ }^{1}$, Stephen Syampungani ${ }^{3}$ \\ 1 Postgraduate Forest Science Programme, Department of Plant and Soil Sciences, University of \\ Pretoria, Pretoria, South Africa \\ ${ }^{2}$ Zambia Forestry College, Kitwe, Zambia \\ ${ }^{3}$ Department of Plant and Environmental Sciences, Copperbelt University, Kitwe Zambia \\ *Corresponding author: fhandavu@yahoo.com; Address: Zambia Forestry College, P/B 1, Mwekera,
} Kitwe, 10101, Zambia.

\section{Highlights}

- Socio-economic factors (gender, age, education, wealth, household size, residence status) are significant determinants of forest products use.

- Household size significantly influenced agriculture expansion and population growth.

- Agriculture expansion and population growth are significant determinants of changes in land-use and land-cover.

- High level of dependence on forest products among local communities

- Consideration of socio-economic factors is critical when developing sustainable forest management policies and strategies.

\begin{abstract}
This study examined socio-economic factors that influence land-use and land-cover dynamics in the Copperbelt miombo woodlands of Zambia. Data were collected through household surveys and focus group discussions. All households that have lived in the area for 5 years and above were considered eligible to participate in the survey. A total of 372 households and 30 discussants within a 5-km buffer zone of the forest reserves were selected for interview. Pearson's Chi-square tests were used to test association between independent variables (gender, age, education, wealth status, and household size) and use of forest products. Furthermore, binary logistic regression models were developed to examine determinants of forest products use and land-use and land-cover change. The chi-square results revealed a strong association among the following; charcoal production with gender, age and wealth; use of construction poles with household size; firewood collection with wealth; wild fruits collection with gender and household size; caterpillar collection with education; honey harvesting with gender and wealth; wild vegetable collection and use with education; use of thatching grass with wealth and household size; livestock fodder use with wealth and level of education; collection and use of bush meat with age and residence status; collection of material for brooms with age and wealth respectively. The logistic regression model results revealed that charcoal, construction poles, wild fruits and animal fodder were statistically significant at $1 \%$ level while, honey, thatching grass and bush meat were significant at 5\%. Gender, age, education, wealth status, household
\end{abstract}


size and residence status were significant determinants in the use of various forest products. Furthermore, the regression model showed that agriculture expansion $(\mathrm{p}<0.031)$ and population growth $(\mathrm{p}<0.032)$ were significant determinants of changes in forest cover. The study concludes that there is high level of dependence on forest products by local communities and hence any attempts to avert deforestation should consider addressing social and economic problems faced by local communities.. We further conclude that development of sustainable forest management policies and strategies that provide for inclusion of local ecological knowledge and various utilization practices such as charcoal production into sustainable forest management.

Key words: miombo woodland, socio-economic factor, land-use, land-cover, deforestation

\section{Introduction}

Land-use and land-cover (LULC) change is a complex socio-economic and environmental issue that requires a comprehensive understanding of the interaction and relationship between human induced activities and the environment (Brown et al., 2013). It is arguably the most pervasive socio-economic force driving changes and degradation of ecosystems. LULC change have become a central component in current strategies for managing natural resource and monitoring environmental changes (Tiwari and Saxena, 2011). Studies undertaken on land and forests indicate that fluctuating human demographic patterns particularly population growth, its density and distribution over longer time scales greatly influence land-use (Lambin et al., 2003), quality and extent of forests (Ashraf et al., 2017), with immigration being considered the most important demographic component driving LULC change (Lambin et al., 2003; Verbist et al., 2005; Yohannes et al., 2018). It is argued that in order to improve our understanding of land-use and land-cover relationships, there is need to link LULC change to human actions (Turner et al., 1995; Nurrochmat et al., 2017 ) and with specific attention to the economic drivers behind these actions (Martinez and Mollicone, 2012).

Several studies have been carried out to assess the contribution of forest products to household income provision (Campbell et al., 1991; Sunderlin et al., 2004; Kalaba et al., 2013; Kamwi et al., 2015) and the results showed that forest products are vital in sustaining rural household needs. Forests remain an important source of products and services that are critical to household livelihood support and emergency safeguards (Angelsen et al., 2014). In line with the above, Wunder et al., (2014) referred the contribution of forests to income and diet as the 
supermarket of the wild. A wide range of studies have indicated an important role non-timber forest products (NTFPs) play in supporting rural household income base (Rasmussen et al., 2017). Furthermore, Hickey et al., (2016) noted the role of wild foods in supporting food security and nutrition. For example, it was noted that people living around forests have greater access to forest foods such as wild fruits, leafy greens and bush meat (Ickowitz et al., 2014; Powell et al., 2013, 2015). In addition to food, other products that are of substantial contribution to household subsistence include fuelwood, medicinal plants, construction materials, fodder and other noncash material goods (Sunderlin, et al., 2005; Rasmussen et al., 2017). Access to these forest products is associated with individual characteristics such as gender, age of the household head, household size, education level and total household income, among others (Coulibaly-Lingani et al., 2009).

Socio-economic factors have been reported to influence LULC change. For example, Schwartz and Caro (2003) noted that socio-economic factors alter or deplete forest cover and also alter forest structure and species composition. Among the socio-economic factors, agriculture expansion (Defries and Pandey, 2010; Kamwi et al., 2015; Vu et al., 2014., Sunderland et al., 2017), population growth (Giliba et al., 2011; Kamwi et al., 2015; Ariti et al., 2015; Yohannes et al., 2018), daily livelihood needs (Giliba et al., 2011), oil palm plantation establishment (Austin et al., 2017; Susanti and Maryudi, 2016) and policy shifts and regime change (Ariti et al., 2015; Maryudi and Sahide, 2017; Yohannes et al., 2018; Rahman et al., 2018) are reported to be among the most critical factors driving LULC change. Furthermore, other studies noted that household size, education, period of residence, distance to forest reserve and farmland size (Mitinje et al., 2007; Giliba et al., 2011) influence deforestation and degradation of forest resources. Haule (2014) argues that age structure and gender composition have important implications on influencing the pace and/or extent of deforestation. On the other hand, Babulo et al., (2008) noted that factors that condition a house's economic reliance on forest environmental resources may vary depending on resource endowment of the household, household's demographic and economic characteristics. Given this scenario, understanding demographic and economic characteristics of the communities in a given area would provide for contribution towards understanding changes in forest cover. Furthermore, the dual role of human beings in contributing to the cause and experiencing the cause of LULC change processes emphasises the need for better understanding of the interactions and linkages between humans 
and the terrestrial environment (Berkes and Folks, 1998; Ungirwalu et al., 2017., Nurrochmat et al. 2017, Pudyatmoko et al., 2017). Currently, the major environmental challenge faced in Zambia is deforestation and forest degradation. Based on the Integrated Land-use Assessment (ILUA) 2000-2014 report (ILUA, 2017), the official annual deforestation rate for Zambia is estimated at approximately 276,021 hectares per annum, a figure poised to be one of Africa's highest deforestation rates per annum.

Although there have been some studies on socio-economic aspect of forest resource use and its influence on LULC change in sub-Saharan Africa (Tugume et al., 2015; Alelign et al., 2011; Giliba et al., 2011; Nzunda et al., 2013), variations in ethnicity and cultural orientation influence use of forest resources differently. Furthermore, differences in demand-led variability in biophysical and socio-economic factors have been reported to lead to countries experiencing different rates and trajectories of land use (see Ashraf et al., 2017). Little is known about the influence of socio-economic factors on LULC change in Zambia and hence a deeper understanding of the human dimension of this phenomenon is desirable. Few studies (e.g. Chileshe, 2005; Umar, 2014) have been undertaken to analyse land tenure and rural livelihoods. However, these studies did not critically look at socio-economic factors that influence LULC change. Therefore, developing an understanding of the influence of socio-economic factors on forest products use and land-use and land-cover dynamics will contribute to developing sustainable land-use and resource management policies. The objective of the study was to address a number of key questions namely: (i) What are the influences of the demographic characteristics on land-use and land-cover change in the study area? (ii) What type of land-uses are in the study area? (iii) What influence does a household's socio-economic status have on resource use? (iv) What are the major socio-economic drivers of land-use and land-cover change?

\section{Materials and methods}

\subsection{Description of the study sites}

The study was undertaken in Miengwe and Katanino catchment areas, both situated in Masaiti District of Zambia and located approximately $90 \mathrm{~km}$, south of Ndola town along the Ndola - Kapiri-Mposhi road. Miengwe Forest reserve lies between latitude $13^{0} 24^{\prime} 05^{\prime \prime S}$ and longitude $28^{0} 49^{\prime} 00^{\prime \prime E}$ (Figure 1), with a gross area of 8, 094 hectares. The forest reserve is 


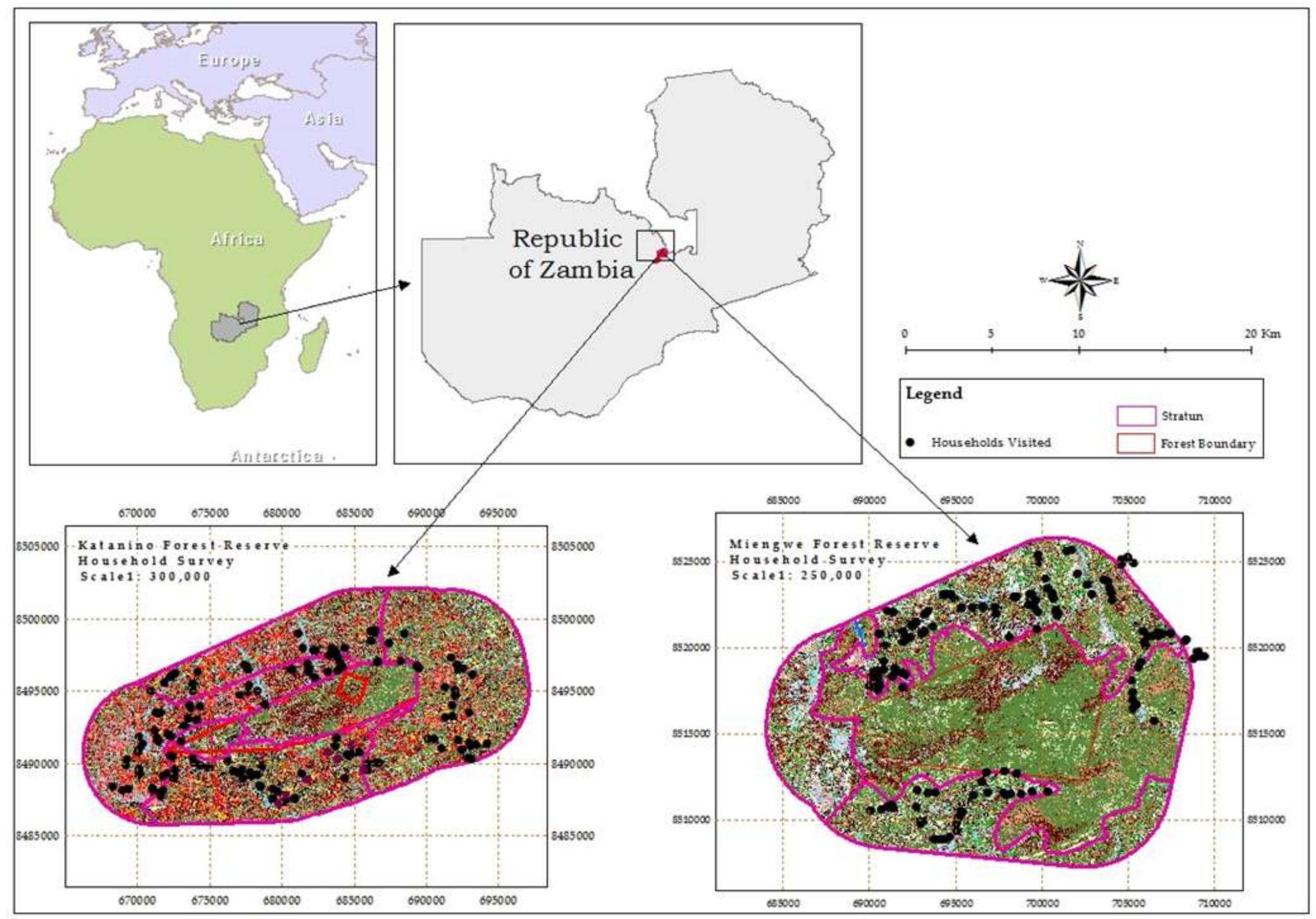

Figure 1: Map showing the location of the study areas and participating households in each study area 
shared by three chiefdoms namely: Mushili, Chiwala and Nkambo. Katanino forest reserve lies between $13^{0} 25^{\prime} 00^{\prime \prime S}$ and $13^{\circ} 45^{\prime} 00^{\prime \prime} \mathrm{S}$ and $28^{\circ} 25^{\prime} 00^{\prime \prime E}$ and $28^{0} 40^{\prime} 00^{\prime \prime E}$ at an altitude of 1200 $\mathrm{m}$. The forest has a gross area of 4, 532 hectares and falls within four (4) chiefdoms namely; Mushili, Malembeka, Nkole and Nkambo.

The forests occur at almost the boundary of Copperbelt and Central Provinces. The forest areas occur on Katanga rock system and fall in one agro-ecological zone (Zone III) and receive rainfall averaging $1200 \mathrm{~mm}$ per annum and experience three distinct seasons based on rainfall and temperature namely; hot dry season (September - November), hot wet season (December April) and the cold dry season (May - August) (Syampungani, 2008). The rainfall is unimodal and occurs between November and March.

\subsection{Socioeconomic profile}

The inhabitants of the two study areas are traditionally Lamba speaking people, though since the 1990s, the area has seen an influx of people from other parts of Zambia. The local communities' main economic activities are heavily dependent on rain-fed slash and burn subsistence farming, charcoal production and trading (Njovu et al., 2004). Other livelihood systems include fishing, hunting, and fruit trade, bee keeping (Kalaba, 2005) and gardening.

\subsection{Sampling design and data collection}

\subsubsection{Site selection}

The two study sites were purposefully selected based on a set of criteria used to represent various socio-economic conditions. First, the study sites have experienced massive changes in land-use/land-cover over the last thirty one years. The catchment areas have been extensively used for income sources which have influenced patterns of forest resource use and dependence. One other reason for selecting the areas with similar characteristics was to provide generalizable results from close replicates to help build a cumulative knowledge base. On the other hand, Katanino forest reserve has previously been jointly managed by local communities and Government under Joint Forest Management (JFM) scheme. The selection of the sites also provided an opportunity to compare between human dominated landscapes and the protected forest reserves falling under formalised management regimes. It is our view that this selection criteria covers key components that depict interaction between the environment (natural forest), 
human capital (demographic pressure), and economic pressure (presence of local small farmers) (see Boissiere et al 2014).

\subsubsection{Sampling design}

The first step involved identifying all the clusters falling within 5-km radius from the forest reserve boundaries. A 5-km buffer was arrived at to specifically capture information from households who really depend on the forests and assessing the connectivity of communities to the forest reserves and associated patterns of resource use. This is in line with Obua et al. (1998) who observed that people within 5- $\mathrm{Km}$ range from the forest reserve tend to interact more frequent and intense with the forest reserve. With the help of traditional leaders, we identified 78 (40 in Miengwe and 38 in Katanino) clusters falling within the 5-km buffer from which individual households were randomly selected for the study. A total of 1, 488 households (776 and 712 households in Miengwe and Katanino, respectively) were recorded from all the identified clusters. Thereafter, random sampling using lottery method (Singh and Masuku, 2014) was employed to select participants from each of the cluster list at $25 \%$ sampling intensity, which is higher than the $20 \%$ recommended by other studies (see Adhikari et al., 2004) as the minimum size considered to be a representative sample for the population. We conducted a household survey using a semi-structured questionnaire in 372 selected households (194 and 178 households in Miengwe and Katanino, respectively) (Fig. 1). All farm owners/households that have been resident in the area for 5 years and above were eligible to participate in the survey. We interviewed household heads or the next of kin in each household. If we did not find any eligible person or in an event that the household refused to participate, another randomly selected household was used to replace that household (see Bong et al., 2016). The sampling unit was a household while the unit of observation was the head of the house or next of kin. A household was defined as a group of people living together, making common arrangements for food and other essentials for survival (FAO, 2010). Prior to undertaking the survey, the questionnaire was pre-tested on ten households within the study area (these were exempted from the main survey) to check for errors and ambiguity and hence improve the validity of the survey tools (see Babbie and Mouton, 2014; Barribeau et al., 2015).

We used focus group meetings to assess a number of issues related to community resource use, household income generating activities, changes in forest cover and factors that drive the changes and also to develop a community based wealth ranking criteria. According to Morgan 
(1996), focus group interview is the purposeful use of interaction designated to generate qualitative data. He identifies three major components of focus group discussion as (i) method devoted to data collection, (ii) interaction as a source of data and (iii) the active role of the researcher in creating group discussion for data collection. In the study, we purposively identified traditional leaders, who have knowledge of forest cover changes and their drivers, forest resource use and local members' socio-economic status. Some of the Focus Group Discussion (FGD) participants were suggested by traditional leaders during our initial visit. In the case of Katanino study site, three of the FGD participants had been key members of the Joint Forest Management (JFM) committee. We desired to identify and select FGD members that were especially knowledgeable or experienced with rural household incomes needs, land use practices and were willing to participate and able to communicate experiences and provide opinions in a reflective and articulate manner. A total of 30 discussants (16 for Miengwe and 14 for Katanino, respectively) participated.

\subsubsection{Data collection}

The two data collection methods employed was focus group discussions and administration of semi-structured questionnaire. The questionnaire was prepared in English and individual questions were orally translated into the local language (Bemba/Lamba) while administering to respondents. Six trained research assistants who were good at both English and the local language participated in the exercise. The questionnaire included several sections covering the following areas; general household socio-economic data (demographics, assets and land-use) (see also Kamwi et al., 2015), level of dependence on forest products and income generating activities. Local community members who were familiar with the study sites were engaged to help with locating the selected farms/households. Upon location of the households and prior to administering the questionnaire, coordinates were taken using a hand-held Global Positioning System (GPS) equipment to ensure that only households within the 5-km buffer were captured.

The sampled households were stratified by wealth classes generated during focus group discussion. Proportion of wealth categories were divided into four classes, namely: Very poor $(n=78)$, Poor $(n=189)$, Rich $(n=74)$ and Very rich $(n=31)$ (see Appendix A). Wealth ranking based on Participatory Rural Appraisal (PRA) technique of household mapping as provided during Focus Group Discussion was undertaken. The discussants were guided to align their 
household wealth ranking process to include socio-economic attributes such as amount of land cultivated, size and style of houses owned, quality of household assets, livestock ownership, income from off-farm agricultural activities (see Richards et al., 1999). The card game method was used for the wealth ranking exercise to identify local criteria used to differentiate households based on wealth and well-being (see Mukherjee, 1992).

Furthermore, four (4) focus group discussion meetings (two per study site) were carried out in both Miengwe and Katanino catchment areas. These meetings consisted of 6-9 discussants per group (e.g. Appendix B). The information gathered from focus group discussions was used through triangulation technique (see also Kamwi et al. 2015) to validate data obtained from questionnaires with focus group interview data to provide in-depth understanding of community activities. In particular, issues such as development of criteria for wealth ranking, migration of households into study sites, and community resource use were discussed. The meetings lasted approximately 90 minutes and were all moderated by the researcher and one assistant. A voice recorder was used to capture the sessions.

\subsection{Data analysis}

Quantitative data were analysed using Statistical Package for Social Sciences (IBM SPSS) software version 23 (IBM Corp. Released 2015. IBM SPSS Statistics for Windows, Version 23.0. Armonk, NY: IBM Corp). The main statistical analysis methods used to analyse the quantitative data were both descriptive and inferential statistical methods (Giliba et al., 2011; Pallant, 2014). Descriptive statistics such as mean values, standard error of the mean, frequency counts and percentages of observed attributes (Giliba et al., 2011) were used to explain demographic characteristics of communities within the 5-km buffer. We examined respondents' perceived roles of household members in collection of forest products. The Pearson's Chi-square test of association was used to show the levels of association between independent variables and frequency of use of forest products. In-depth data was analysed through content analysis. Furthermore, in order to assess the socio-economic variables that were determinants of communities' use of forest products and perceived land-cover loss, a series of binary logistic regression models were developed (see Coulibaly-Lingani et al., 2009; Kamwi et al., 2015). The logistic regression model is a suitable statistical tool when determining the influence of explanatory variables on the dichotomous dependent variables (i.e. with only two categories or 
values), when the former are continuous, categorical or dummy variables (Peng et al., 2002; Coulibaly-Lingani et al., 2009). The model contained eight (8) explanatory variables which included the following: gender, age of respondent, education level, wealth, household size and residence status, which were introduced simultaneously to assess factors influencing the use of forest products.

The logit is the natural logarithm $(\mathrm{ln})$ of odds of $\mathrm{Y}$, and odds are ratios of probabilities $(\pi)$ of Y happening to probabilities $(1-\pi)$ of $Y$ not happening. The logistic model is specified as:

$$
\operatorname{logit}(Y)=\operatorname{In}\left(\frac{\pi}{1-\pi}\right)=\beta_{0}+\beta_{1} X_{1 i}+\beta_{2} X_{2 i}+\cdots+\beta_{k} X_{k i}
$$

Where $\beta_{0}$ is the intercept and $\beta_{1}, \beta_{2} \ldots \beta_{\mathrm{k}}$ are the coefficients of the independent variables $\mathrm{X}_{1}, \mathrm{X}_{2} \ldots \mathrm{X}_{\mathrm{k}}$.

The response variables for the logistic regression model applied in this study were various forest products that communities collect. Use of forest products was a binary choice variable $(1=$ yes and $0=$ otherwise) that helped to establish whether a household collects any products from the forest or not. Furthermore, the response variables for the logistic regression model on causes of land-cover change were: charcoal production, agriculture expansion, population growth and settlements, which were also defined as binary variables with a value 1 for respondents agreeing to either of the perceived causes or 0 for otherwise. Other causes such as lack of conservation knowledge, firewood harvesting and honey harvesting were not included in the logistic regression model because they were mentioned by few respondents, thereby making them insufficient for inclusion in the model (see Kamwi et al., 2015). Qualitative data from focus group discussions was analysed through content analysis, whereby the discussions were objectively and subjectively analysed (Hsieh and Shannon, 2005; Kamwi et al., 2015).

\section{Results}

\subsection{Household demographics characteristics}

Table 1 shows the household demographic characteristics of the study areas. Results from the 372 respondents showed that $65.3 \%(n=243)$ were males and $34.7 \%(n=129)$ were females. Of the interviewed respondents, $56.7 \%(\mathrm{n}=211)$ attended grade $1-7$ and $30.4 \%(\mathrm{n}=113)$ grade $8-12$, while only $1.6 \%(n=6)$ attended tertiary education. Those that never went to school accounted for 
$11.3 \%(\mathrm{n}=42)$. With respect to their wealth status, the sampled households consisted of $71.8 \%$ poor and very poor families and only $28.2 \%$ of the households belonged to the rich and very rich categories.

Results on ethnicity of participating household heads revealed a total number of 24 ethnic groups. Of these, the 5 most dominant tribes included the following; Lamba (37.4\%), Bemba (16.4\%), Lala (15.1\%), Tonga (8.6\%) and Lenje (4.8\%). The rest in the minority included the following: Namwanga, Chewa, Ngoni, Swaka, Ushi, Tumbuka, Kaonde, Ndebele, Lozi, Luvale, Nsenga, Bisa, Shona, Zezulu, Lunda, Soli, Karanga, Kunda, and Lungu respectively.

Table 1: Demographic characteristics of participating households

\begin{tabular}{|c|c|c|}
\hline \multicolumn{3}{|l|}{ Demographic characteristic } \\
\hline \multirow[t]{2}{*}{ Gender of household respondents } & Male headed & $65.3 \%$ \\
\hline & Female headed & $34.7 \%$ \\
\hline Average household size & \multicolumn{2}{|l|}{$8.33 \pm 0.225$} \\
\hline Av. Land holding size & \multicolumn{2}{|c|}{$14.35 \pm 18.511$ hectares } \\
\hline Av. Cultivated land size & \multicolumn{2}{|c|}{$3.66 \pm 3.676$ hectares } \\
\hline \multirow[t]{2}{*}{ Household status } & Indigenous & $40.5 \%$ \\
\hline & Migrant & $59.5 \%$ \\
\hline \multicolumn{3}{|l|}{ Wealth categories } \\
\hline Very rich & \multicolumn{2}{|l|}{$8.3 \%(n=31)$} \\
\hline Rich & \multicolumn{2}{|l|}{$19.9 \%(\mathrm{n}=74)$} \\
\hline Poor & \multicolumn{2}{|l|}{$50.8 \%(\mathrm{n}=189)$} \\
\hline Very poor & \multicolumn{2}{|l|}{$21 \%(\mathrm{n}=78)$} \\
\hline
\end{tabular}

We investigated farm sizes owned by individual land owners. The mean farm size in the study areas was $14.35 \pm 18.511$ hectares, with approximately $40 \%$ of the households falling in the 0-5-hectare category. The mean cultivated land size for two study sites was $3.66 \pm 3.676$ hectares per household.

\subsection{Factors affecting land-use change}

\subsubsection{Population distribution}

Population distribution is influenced by migration, a complex process driven by many factors. The study revealed that majority of the respondents was migrants $(59.5 \%)$ while local inhabitants accounted for $40.5 \%$ of the respondents (Table 1). Forces of migration were 
investigated during focus group discussions. Discussants indicated that attraction into a new area was mainly stimulated by factors such as: good soils, availability of productive land and abundance of rainfall. Similarly, scarcity of farmland, decreasing agricultural productivity, erratic rainfall, limited income opportunities was reported as causes of people leaving an area. Furthermore, it was revealed that majority of those that migrated were informed by relatives or close associates. For example, when asked why people have been flocking to the area, one male discussant in Katanino site recalled the drought of the 1996/1997 farming season by saying;

"The drought of 1997 left us with shame to an extent where our pride of being a maize belt province was no longer on our lips. We survived entirely on a government initiative of "food for work" just to have at least a meal for the day. The year that followed, I had no option but relocate to this area where rainfall is still abundant."

\subsection{Farming practices and production trends}

Results on the main farming practices showed that local communities engage in three (3) major practices namely: shifting cultivation $(32 \%, \mathrm{n}=119)$, crop rotation $(29 \%, \mathrm{n}=108)$ and intensive mono-cropping (26\%, $\mathrm{n}=95)$ (Fig. 2). The crops mainly grown in the study areas are maize (Zea mays) (staple food), sweet potatoes (Ipomea batatas) and groundnuts (Arachis hypogaea). In terms of production trends, majority of respondents indicated low productivity $(69.2 \%)$ for maize, while response on sweet potatoes showed a slightly higher trend (56.5\%). Respondents attributed the low productivity for maize mainly to loss of soil fertility, lack of farming inputs, insufficient rainfall and non-availability of extension services. As for sweet potatoes, the lack of impressive yield was attributed to insufficient rainfall and attack on tubers by moles. 


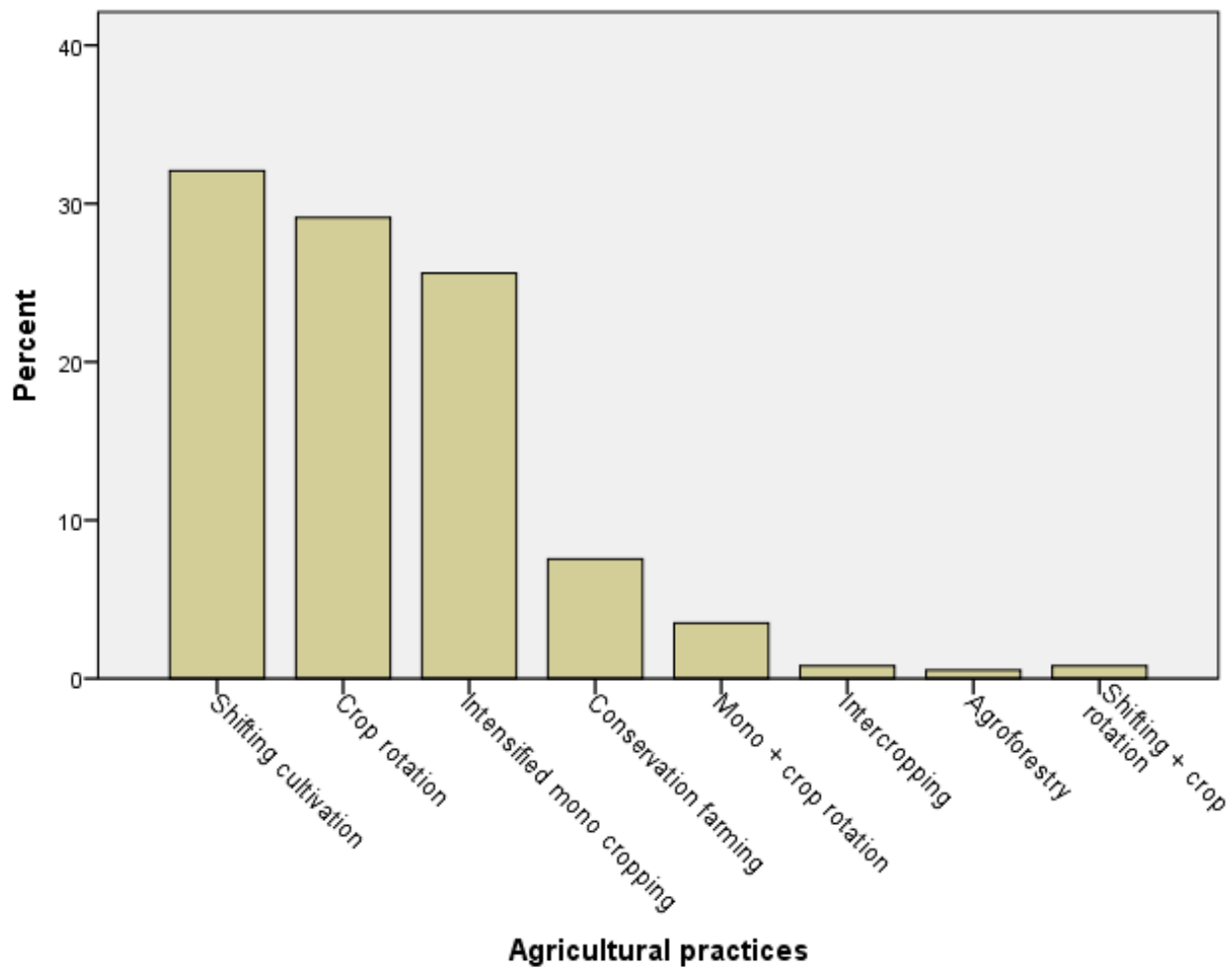

Figure 2: Farming practices prominently engaged by households in the study area

\subsection{Sources of income and community forest resource utilisation}

\subsubsection{Household income sources}

Figure 3 shows that sale of farm produce (58.2\%) was ranked to be the most important source of income in the study areas. Furthermore, charcoal production and sale (52.5\%) and wild food harvesting (45\%) were ranked to be the second and third sources of income in the study sites. Income from family business and piecework accounted for $34.9 \%$ and $29 \%$ respectively. 


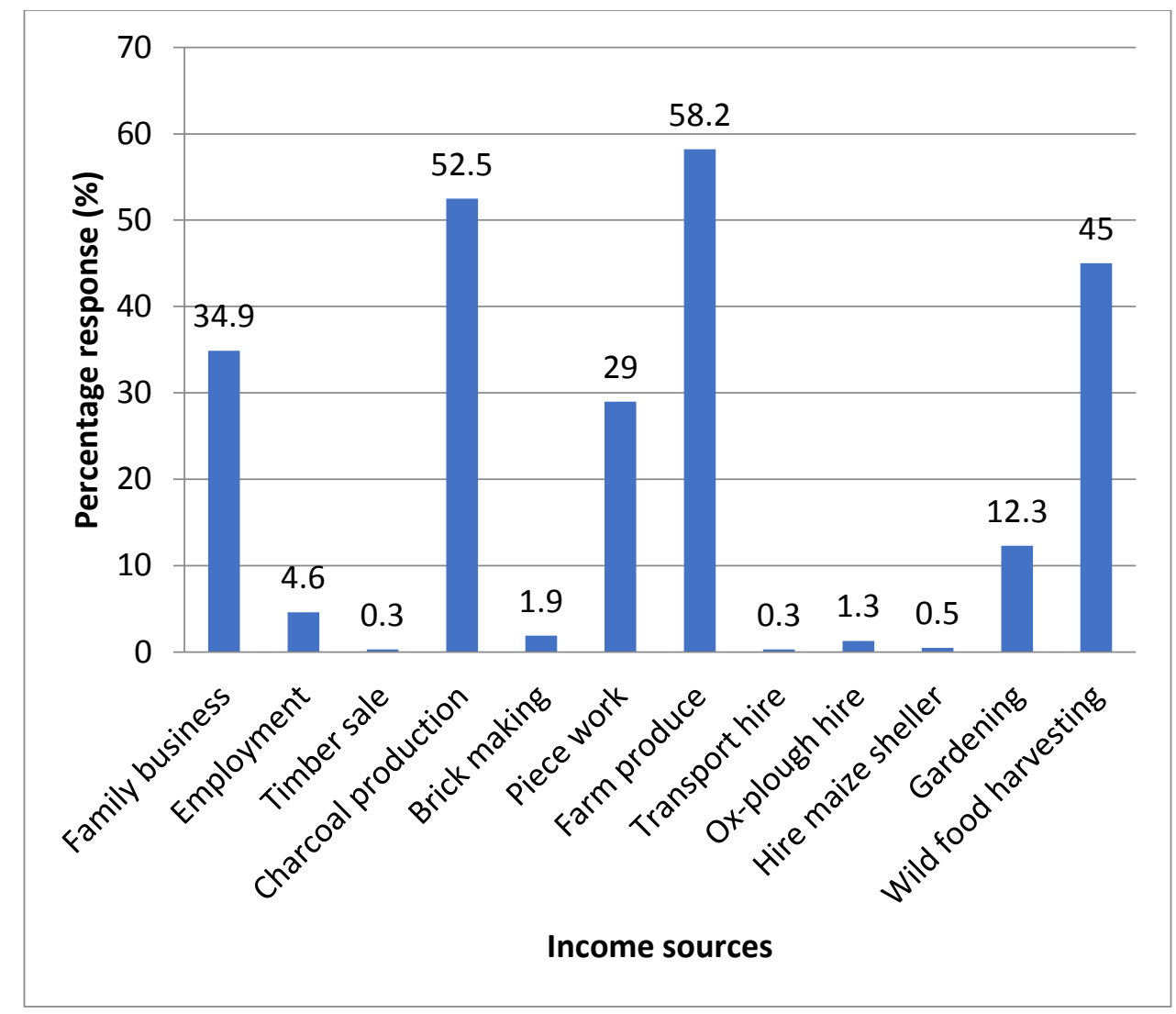

Figure 3: Household income sources in the study areas

Furthermore, other sources of income included livestock production with chickens (33.3\%), chicken + goats $(16.4 \%)$ and goats $(7.5 \%)$ being the most sold. However, focus group discussion results indicated that charcoal production and sale was a major source of income in the area. For example, some of the discussants around Katanino forest reserve had this to say;

"farming inputs are very expensive to afford so we treat this forest as our reserve bank from which we draw a living through manufacturing and sale of charcoal".

Discussants indicated that charcoal bags are packaged in various bag sizes according to market points (e.g. Fig. 4). Very few households engaged in specialised skills such as the sale of hand crafts and garden chair production displayed (Appendix C). 


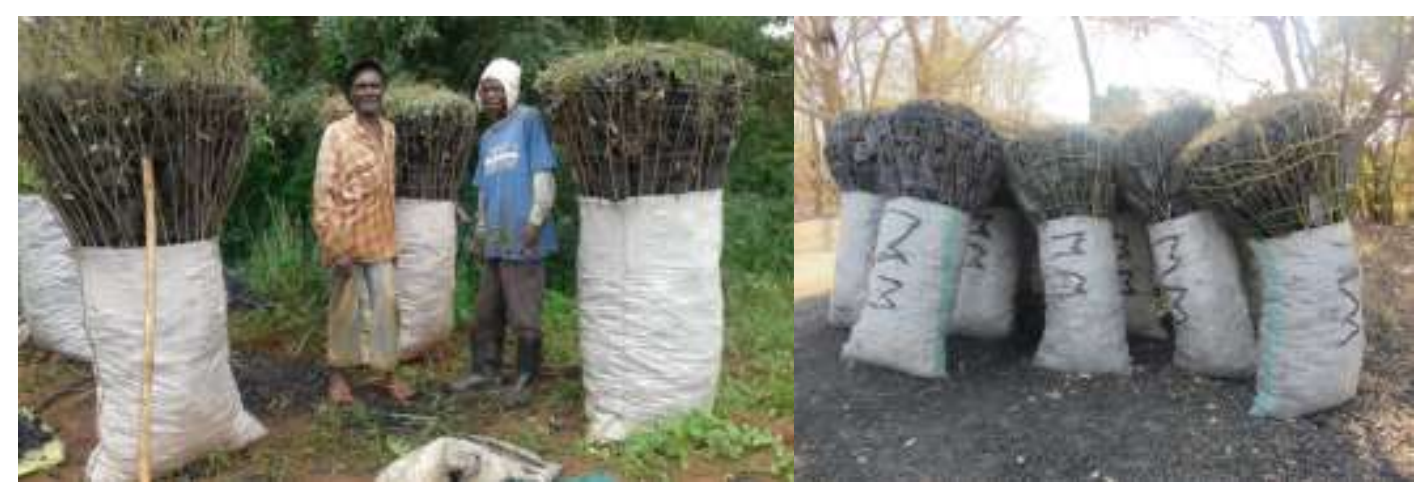

a.

b.

Figure 4: Photos showing charcoal bags read for transportation to Ndola (a) and Lusaka (b)

Overall, pooled results on level of dependence showed that $98.1 \%$ of the respondents indicated that they highly depend on forest for various products. Rural household's dependency on fuel wood for energy was investigated and results indicated that $96 \%$ of the communities use firewood, while only $4 \%$ use charcoal as the main household energy source. In addition, majority of the firewood users rely on charcoal for household supplementary energy needs.

Figure 5 shows a total of 16 forest products frequently obtained from the two study sites. Results showed that the highest proportion of households engaged in mushroom (90.9\%), firewood $(90.9 \%)$, wild fruits $(88.7 \%)$, thatching grass $(83.6 \%)$, construction poles $(75.3 \%)$, wood fibre (74.5\%), medicine (72\%), charcoal (68.3\%), honey (59.9\%) and wild vegetables (55.4\%), which constitute the ten (10) most frequently extracted forest product in the study areas. 


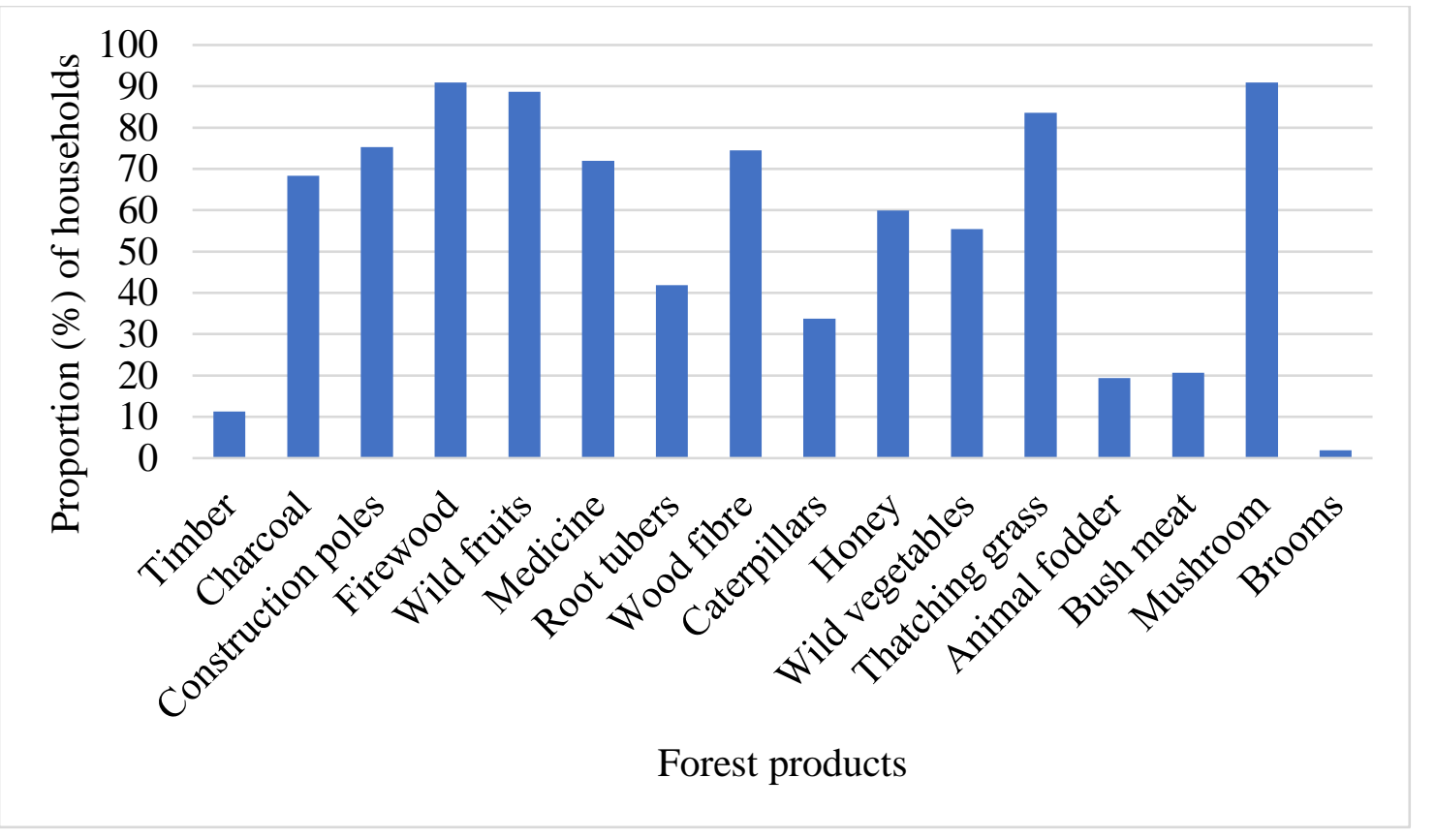

Figure 5: Proportion (\%) of households collecting various forest products

In addition, association between predictor variables (gender, age, education, wealth status, and household size) and forest products use was investigated. The results showed significant level of association between some explanatory variables and use of some of the forest products. The study revealed statistical evidence of association among the following; gender, age and wealth with charcoal production $\left(X^{2}=9.145, p<0.002 ; X^{2}=17.928, p<0.006 ; X^{2}=8.841, p<\right.$ $0.031)$, household size with use of construction poles $\left(X^{2}=22.831, p<0.000\right)$, wealth with firewood collection $\left(X^{2}=10.193, p<0.017\right)$, gender and household size with collection and use of wild fruits $\left(X^{2}=10.839, p<0.001 ; X^{2}=15.966, p<0.007\right)$, education with caterpillar collection and use $\left(X^{2}=7.993, p<0.046\right)$, gender \& wealth with wild honey harvesting $\left(X^{2}=\right.$ $\left.6.345, \mathrm{p}<0.012 ; \mathrm{X}^{2}=9.036, \mathrm{p}<0.029\right)$, education with wild vegetable collection and use $\left(X^{2}=\right.$ 10.327, $\mathrm{p}<0.016)$, wealth and household size with use of thatching grass $\left(\mathrm{X}^{2}=10.167, \mathrm{p}<\right.$ $\left.0.017 ; X^{2}=16.777, \mathrm{p}<0.005\right)$, wealth and education with livestock fodder $\left(X^{2}=54.209, \mathrm{p}<\right.$ $\left.0.000 ; X^{2}=21.272, p<0.000\right)$, age and residence status with use of bush meat $\left(X^{2}=21.581 .928, p\right.$ $\left.<0.000 ; \mathrm{X}^{2}=4.940, \mathrm{p}<0.026\right)$; age and wealth with collection of materials for making brooms $\left(X^{2}=35.199, p<0.000 ; X^{2}=15.980, p<0.001\right)$ (Table 2). However, no significant association 
Table 2: Explanatory variables and associated use of forest products

\begin{tabular}{|c|c|c|c|c|c|c|c|c|c|c|c|c|}
\hline \multirow{3}{*}{ Product } & \multicolumn{12}{|c|}{ Statistical evidence of levels of association } \\
\hline & \multicolumn{2}{|c|}{ Gender } & \multicolumn{2}{|c|}{ Age } & \multicolumn{2}{|c|}{ Wealth } & \multicolumn{2}{|c|}{ Education } & \multicolumn{2}{|c|}{ Household size } & \multicolumn{2}{|c|}{ Residence status } \\
\hline & $\square 2$ & $\mathrm{p}$-value & $\square 2$ & p-value & $\square 2$ & p-value & $\square 2$ & $\mathrm{p}$-value & $\square 2$ & $p$-value & $\square 2$ & p-value \\
\hline Timber & 1.505 & 0.220 & 4.670 & 0.587 & 2.968 & 0.397 & 3.862 & 0.277 & 4.790 & 0.442 & 7.398 & $0.007^{*}$ \\
\hline Charcoal & 9.145 & $0.002 *$ & 17.928 & $0.006^{*}$ & 8.841 & $0.031^{*}$ & 2.779 & 0.427 & 3.208 & 0.668 & 0.164 & 0.686 \\
\hline Construction poles & 0.077 & 0.782 & 11.934 & 0.063 & 0.371 & 0.946 & 6.834 & 0.077 & 22.831 & $0.000 *$ & 0.119 & 0.731 \\
\hline Firewood & 1.113 & 0.292 & 8.481 & 0.205 & 10.193 & $0.017^{*}$ & 4.051 & 0.256 & 4.585 & 0.469 & 0.002 & 0.969 \\
\hline Wild fruits & 10.839 & $0.001 *$ & 9.152 & 0.165 & 4.430 & 0.219 & 0.912 & 0.870 & 15.966 & $0.007 *$ & 0.078 & 0.780 \\
\hline Medicine & 1.511 & 0.219 & 6.596 & 0.360 & 6.748 & 0.080 & 2.708 & 0.439 & 8.870 & 0.114 & 2.330 & 0.127 \\
\hline Roots/tubers & 1.698 & 0.193 & 10.670 & 0.099 & 4.712 & 0.194 & 0.967 & 0.809 & 1.566 & 0.905 & 1.506 & 0.220 \\
\hline Wood fibre & 0.971 & 0.325 & 7.676 & 0.263 & 7.519 & 0.057 & 1.432 & 0.698 & 5.104 & 0.403 & 0.039 & 0.843 \\
\hline Caterpillars & 1.492 & 0.222 & 6.940 & 0.326 & 4.100 & 0.251 & 7.993 & $0.046^{*}$ & 2.998 & 0.700 & 0.306 & 0.580 \\
\hline Honey & 6.345 & $0.012 *$ & 11.218 & 0.082 & 9.036 & $0.029 *$ & 0.631 & 0.889 & 5.326 & 0.377 & 0.001 & 0.980 \\
\hline Wild vegetables & 1.001 & 0.317 & 4.838 & 0.565 & 3.115 & 0.374 & 10.327 & $0.016^{*}$ & 6.169 & 0.290 & 0.001 & 0.971 \\
\hline Thatching grass & 0.401 & 0.526 & 11.812 & 0.066 & 10.167 & $0.017^{*}$ & 0.221 & 0.974 & 16.777 & $0.005^{*}$ & 0.069 & 0.792 \\
\hline Livestock fodder & 0.000 & 0.993 & 5.676 & 0.460 & 54.209 & $0.000 *$ & 21.272 & $0.000^{*}$ & 6.645 & 0.248 & 0.144 & 0.705 \\
\hline Bush meat & 0.036 & 0.850 & 21.581 & $0.001 *$ & 1.084 & 0.781 & 4.573 & 0.206 & 7.104 & 0.213 & 4.940 & $0.026^{*}$ \\
\hline Mushroom & 0.458 & 0.499 & 8.480 & 0.205 & 1.623 & 0.654 & 1.660 & 0.646 & 4.608 & 0.466 & 2.030 & 0.154 \\
\hline Brooms & 2.109 & 0.348 & 35.199 & $0.000 *$ & 15.980 & $0.001 *$ & 4.548 & 0.603 & 4.010 & 0.947 & 0.703 & 0.704 \\
\hline
\end{tabular}

*Significant at 0.05 level of confidence 
was observed between explanatory variables and use of forest products such as medicine, roots/tubers, wood fibre and mushroom.

\subsubsection{Determinants of forest products utilization}

Several reasons exist why households with varying socio-economic and demographic characteristics depend on forest products differently. This may among others relate to consumption motives and response to varying challenges households come across. In order to establish the likelihood that socio-economic factors influence households' use of forest products, six independent variables (gender, age, education, wealth status, household size and residence status) were entered in the logistic regression model. Overall assessment of the logistic regression model for the use of various forest products revealed positive results. For the HosmerLemeshow Goodness of Fit Test poor fit is designated by a significance value less than 0.05, so to support our models we require values greater than 0.05 . In our study, the chi-square values showed that $\mathrm{p}$-values were larger than 0.05 , implying adequate fit to the data and hence support for the models (Appendix D).

The full models containing predictors that were statistically significant using the Omnibus Test of Model Coefficients were seven (7). Coefficients on charcoal $\left[X^{2}{ }_{(16,372)}=37.756\right.$, $p<$ 0.002]; construction poles $\left[\mathrm{X}^{2}{ }_{(16,372)}=37.756, \mathrm{p}<0.001\right]$; wild fruits $\left[\mathrm{X}^{2}{ }_{(16,372)}=37.756, \mathrm{p}<\right.$ $0.005]$; and animal fodder $\left[\mathrm{X}^{2}(16,372)=37.756, \mathrm{p}<0.001\right]$ were statistically significant at $1 \%$,

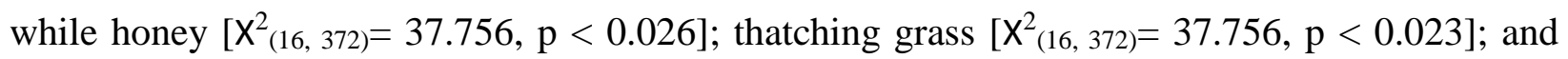
bush meat $\left[\mathrm{X}^{2}(16,372)=37.756, \mathrm{p}<0.024\right]$ were statistically significant at $5 \%$ level (Table 3$)$. 
Table 3: Table showing model performance using the Omnibus Test of Model Coefficients

\begin{tabular}{l|ccc}
\hline Product & Chi-Square & $d f$ & Sig \\
\hline Timber & 25.331 & 16 & 0.064 \\
Charcoal & 37.756 & 16 & $0.002^{* *}$ \\
Construction poles & 38.188 & 16 & $0.001^{* *}$ \\
Firewood & 16.040 & 16 & 0.450 \\
Wild fruits & 34.393 & 16 & $0.005^{* *}$ \\
Medicine & 21.282 & 16 & 0.168 \\
Roots/Tubers & 17.161 & 16 & 0.375 \\
Wood fibre & 21.251 & 16 & 0.169 \\
Caterpillars & 24.144 & 16 & 0.086 \\
Honey & 28.728 & 16 & $0.026^{*}$ \\
Wild vegetables & 25.973 & 16 & 0.054 \\
Thatching grass & 29.175 & 16 & $0.023^{*}$ \\
Animal fodder & 90.297 & 16 & $0.000^{* *}$ \\
Bush meat & 28.958 & 16 & $0.024^{*}$ \\
Mushroom & 19.426 & 16 & 0.247 \\
\hline
\end{tabular}

*Statistically significant at $5 \%$ level of significance; and $* *$ indicates significance at $1 \%$ level.

Furthermore, in terms of influence of socio-economic determinants on use of forest products, the output of the logistic regression model revealed that though with varying levels of dominance, gender, age of household head, education, wealth and residence status were significant determinants of use of specific forest products. For example, results revealed that collection and use of timber was found to be significantly influenced by residence status ( $\mathrm{p}<$ 0.013), gender and age had significant influence on charcoal production $(\mathrm{p}<0.003, \mathrm{p}<0.002)$, age class (36-55 years) had influence on use of construction poles ( $\mathrm{p}<0.037$ ), gender and household size (11-15 class) had influence on collection and use of wild fruits $(\mathrm{p}<0.001, \mathrm{p}<$ 0.035), age had influence on collection of roots and tubers $(\mathrm{p}<0.030)$, age groups $36-55 \& 56$ - 75 years influenced the collection and use of wood fibre $(p=0.040, p<0.030)$, secondary education level ( $\mathrm{p}<0.046)$, and wealth status of households $(\mathrm{p}<0.049)$ influenced the gathering of caterpillars, honey gathering and use were influenced by gender of household head $(\mathrm{p}<0.011)$ and age groups 36-55 \& $56-75$ ( $<<0.015)$, wild vegetable gathering and use was statistically influenced by level of education $(\mathrm{p}<0.018)$, collection and use of thatching grass was influenced by age groups $(16-35, \mathrm{p}<0.041 ; 36-55, \mathrm{p}<0.031 ; 56-75, \mathrm{p}<0.048)$, collection and use of 
livestock fodder was influenced by age group $(16-35, \mathrm{p}<0.038)$; education $(\mathrm{p}<0.005)$ and wealth status $(\mathrm{p}<0.001)$, and finally household use of bush meat was influenced by age $(\mathrm{p}<$ $0.037)$ and residence status $(\mathrm{p}<0.018)$ (Appendix E).

Table 4: Percentage response on levels of abundance of forest products per study site

\begin{tabular}{l|cccc|cccc}
\hline \multirow{3}{*}{ Product } & \multicolumn{3}{|c|}{ Level of abundance (\%) Miengwe } & \multicolumn{3}{c}{ Level of abundance (\%) Katanino } \\
\cline { 2 - 9 } & Abundant & $\begin{array}{c}\text { Not } \\
\text { abundant }\end{array}$ & $\begin{array}{c}\text { Not } \\
\text { found }\end{array}$ & $\begin{array}{c}\text { No } \\
\text { idea }\end{array}$ & Abundant & Not & Not & No \\
abundant & found & idea \\
\hline Timber & 5.7 & 6.2 & 82.5 & 6.7 & 6.7 & 7.3 & 84.8 & 1.1 \\
Charcoal & 54.1 & 18.6 & 0.5 & 26.8 & 54.5 & 9.0 & 2.8 & 33.7 \\
Construction Poles & 73.7 & 14.4 & 0.0 & 11.9 & 46.6 & 11.2 & 1.1 & 41.0 \\
Firewood & 85.1 & 8.8 & 0.0 & 6.2 & 77.0 & 6.7 & 0.6 & 15.7 \\
Wild fruits & 73.7 & 18.0 & 0.5 & 7.7 & 64.6 & 16.3 & 0.6 & 18.5 \\
Medicinal plants & 67.0 & 5.7 & 0.0 & 27.3 & 66.3 & 2.8 & 1.1 & 29.8 \\
Wild tubers/roots & 35.4 & 14.9 & 1.0 & 49.5 & 21.3 & 10.7 & 18.5 & 49.4 \\
Wood fibre & 70.1 & 9.8 & 0.0 & 20.1 & 50.0 & 15.2 & 1.1 & 33.7 \\
Caterpillars & 49.0 & 13.4 & 1.5 & 36.1 & 15.7 & 24.2 & 17.4 & 42.7 \\
Honey & 49.0 & 13.4 & 1.5 & 36.1 & 36.0 & 21.9 & 5.1 & 37.1 \\
Wild vegetables & 52.1 & 10.3 & 0.0 & 37.6 & 38.8 & 6.2 & 3.9 & 51.1 \\
Thatch grass & 86.1 & 6.7 & 0.0 & 7.2 & 60.7 & 10.1 & 2.8 & 26.4 \\
Livestock fodder & 22.1 & 1.0 & 0.5 & 76.3 & 13.5 & 1.1 & 3.9 & 81.5 \\
Bush meat & 13.9 & 16.5 & 22.2 & 47.4 & 5.6 & 4.5 & 81.5 & 8.4 \\
Mushroom & 83.5 & 10.3 & 0.0 & 6.2 & 59.6 & 27.0 & 1.7 & 11.8 \\
Brooms & 1.0 & 0.0 & 0.0 & 99.0 & 1.1 & 0.0 & 3.4 & 95.5 \\
\hline
\end{tabular}

As part of the understanding of the level of abundance of forest products, rural household heads were asked to rank the forest products. Table 4 shows that in Miengwe catchment area, respondents indicated eight (8) most abundant forest products as follows; thatching grass $(86.1 \%)$, firewood $(85.1 \%)$, mushroom $(83.1 \%)$, wild fruits and construction poles $(73.7 \%$ each), wood fibre $(70 \%)$ medicinal plants $(67 \%)$, charcoal $(54.1 \%)$ and wild vegetables. In Katanino study site, results revealed the following order of abundance; firewood (77\%), medicinal plants $(66.3 \%)$, wild fruits (64.6\%), thatching grass (60.7\%), mushroom (59.6\%), charcoal (54.5\%) and wood fibre (50\%). Furthermore, it was observed that there was a high level of community organisation during mushroom gathering in Miengwe study site than in Katanino area. This was evidenced by existence of well organised market outlets where mushroom was sold. Furthermore, in Miengwe, communities formed small groups where each group had specific days within the week when they collected mushroom in Miengwe forest reserve. The mushroom is 
sold in baskets, commonly known as "imiseke" (Fig. 6a) at wholesale order price to locals and people (locally known as "Ba Kungula") from urban areas.

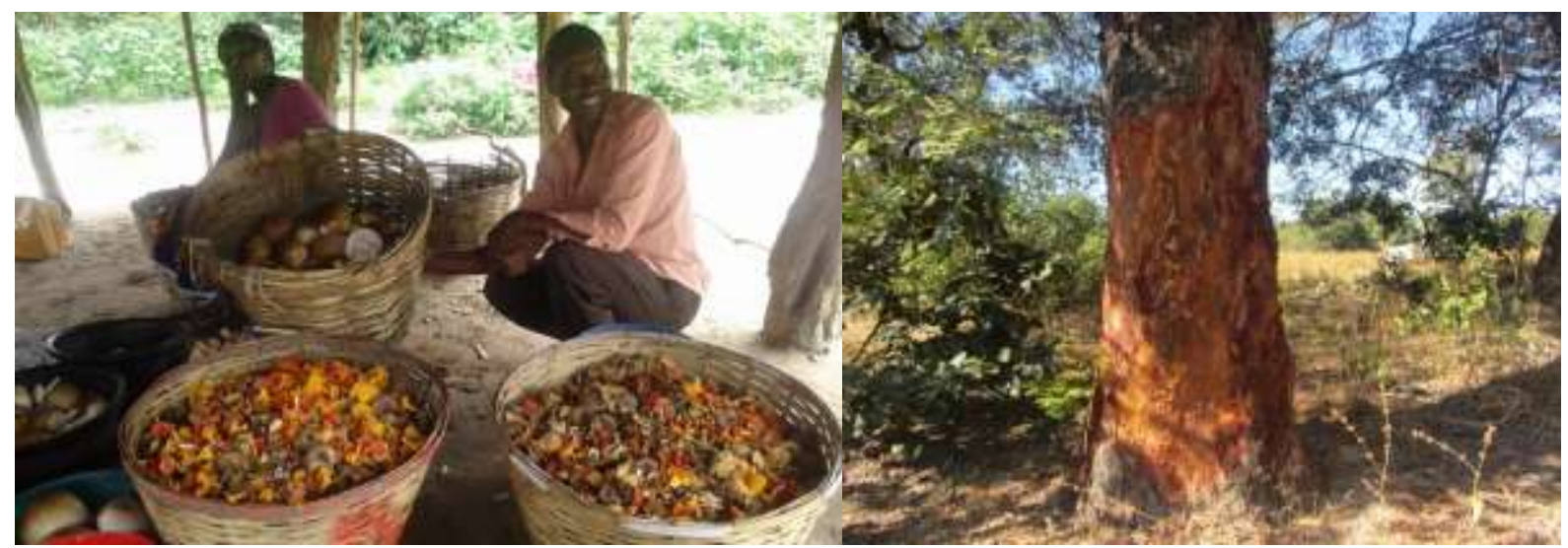

a. Mushroom collected for sale

b. Use of trees for medicinal purposes

Figure 6: Forest products community members obtain from forests around study sites

\subsubsection{Local Ecological Knowledge (LEK) and forest conservation}

We investigated existence of local ecological knowledge systems (norms and cultural values) that help in conservation of the forest resources. The pooled results showed that $82 \%$ of the respondents were aware of local ecological practices that help to conserve the forest resources. Key LEK practices established during the survey were as follows; protection of trees in grave sites (Fig. 7), no cutting of trees along riverbanks, no cutting of fruit trees. Results from this study revealed that protection of burial sites is one of the highly-respected practices among communities.

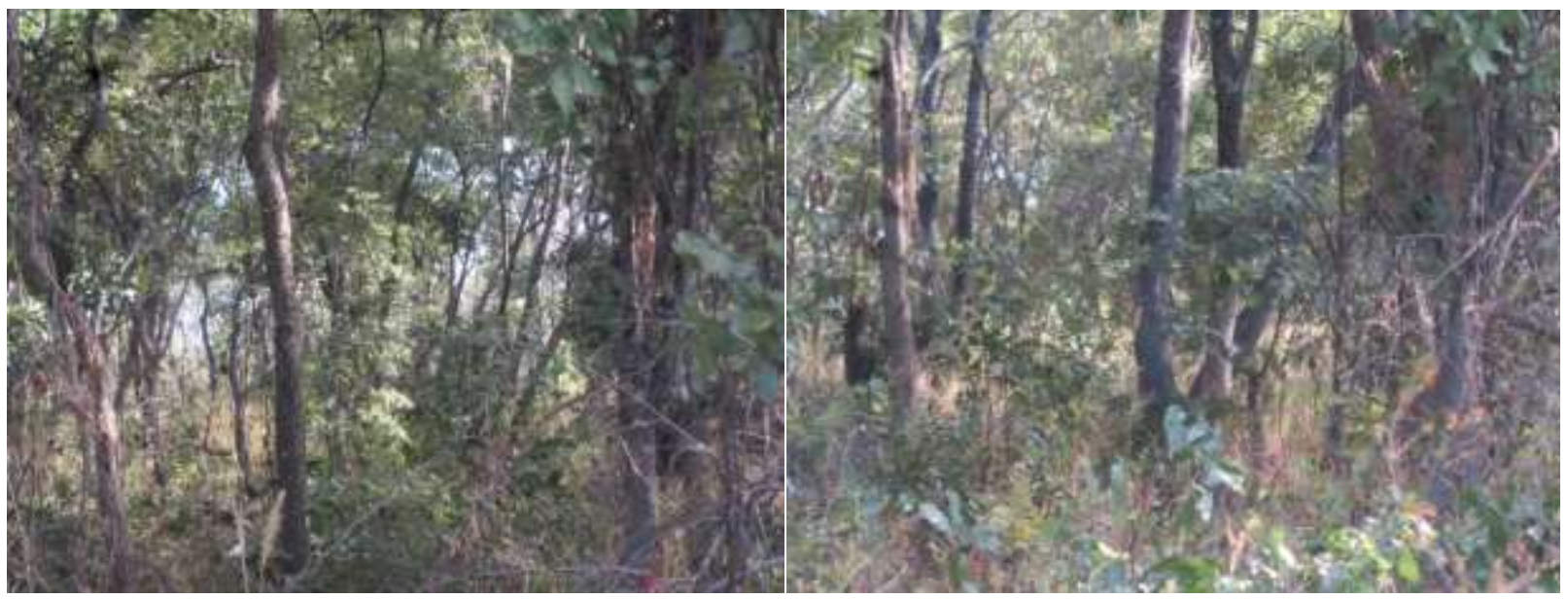

Figure 7: Preserved vegetation at grave sites 


\subsubsection{Land clearance and perceived causes of forest cover loss}

Results indicate that $79 \%$ of the interviewed participants cleared land in the last 10 years in the study sites and the major reasons advanced were; increasing agricultural productivity and loss of soil fertility. Average land cleared per household per annum was $2.1 \pm 3.528$ hectares and the mean cultivated farmland size was $3.66 \pm 3.676$ hectares.

Communities' perceptions on the causes of forest cover loss were investigated in the study. Of the interviewed, $87.1 \%$ of the people noted that there has been a decrease in forest cover over the last 10 years (Fig, 8).

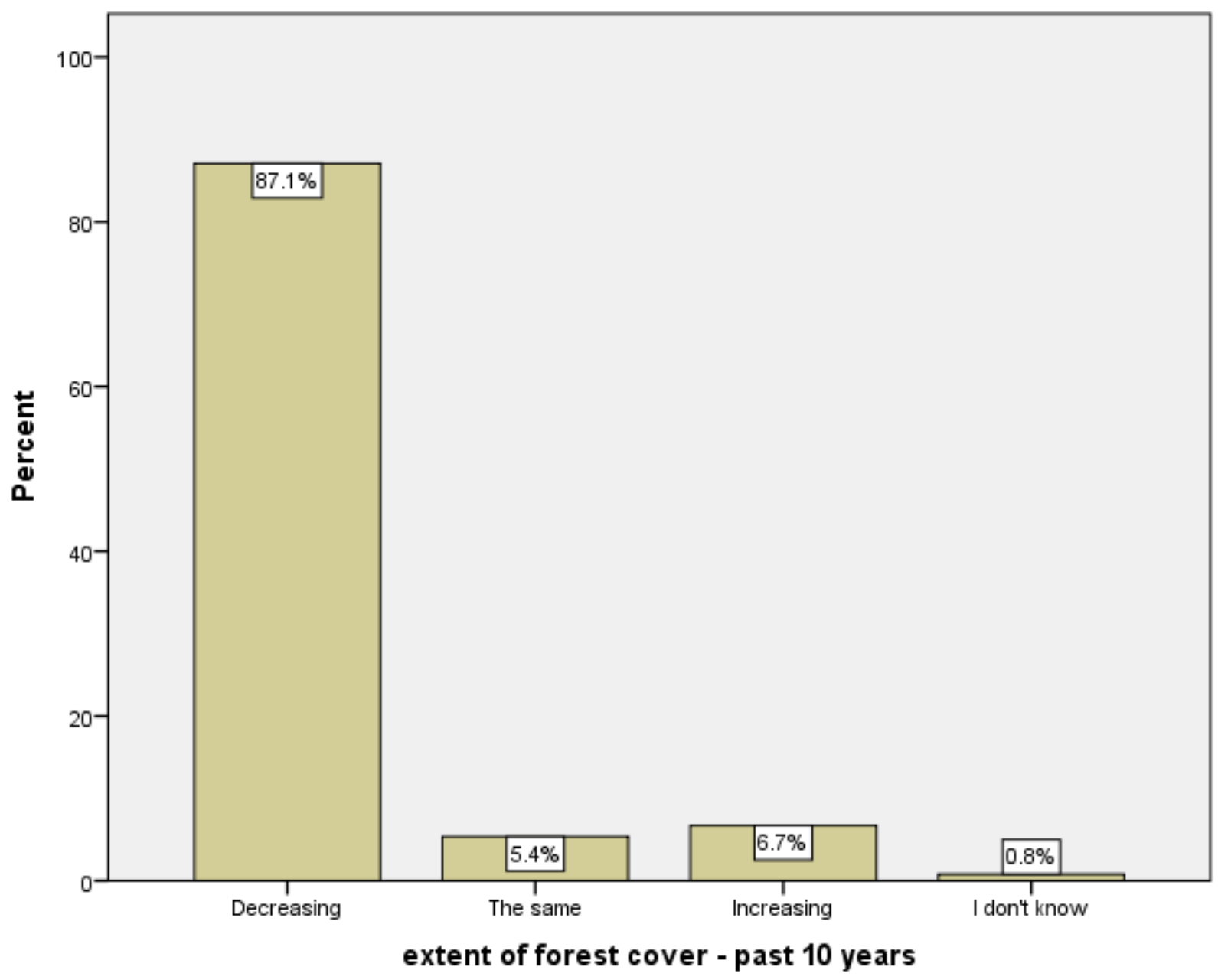

Figure 8: Participants' perception on extent and state of forest cover in the past 10 years 
Table 5 shows that there is a general understanding that charcoal production $(77.2 \%)$ is the main cause of change in land-use and land-cover in the study area. Agriculture expansion was ranked as the second (25.6\%) most important driver of land-use and land-cover change, while population growth $(18.3 \%)$ ranked third, respectively. Drivers such as settlements and firewood harvesting were considered of little influence (6.2 and $0.5 \%$ respectively).

Table 5: Participants' response on causes of land use and land cover change

\begin{tabular}{l|cc}
\hline Perceived causes of forest cover loss & \multicolumn{2}{|c}{ Participant response } \\
\hline & Frequency & Percentage (\%) \\
Charcoal production & 287 & 77.2 \\
Agricultural expansion & 94 & 25.6 \\
Settlements & 23 & 6.2 \\
Population increase & 70 & 18.3 \\
Firewood harvesting & 2 & 0.5 \\
\hline
\end{tabular}

\subsection{Determinants of forest cover loss}

Four logistic regression models were developed to explore the key determinants of the likelihood that charcoal production, agricultural expansion, settlements and population growth could influence forest cover loss. The model contained all the six independent variables (gender, age, education, wealth, household size and residence status). Overall assessment using the Omnibus Test of Model Coefficients revealed that agricultural expansion $\left(X^{2}{ }_{(16,372)}=28.077, p<\right.$ $0.031)$ and population growth $\left(\mathrm{X}^{2}(16,372)=27.985, \mathrm{p}<0.032\right)$ were statistically significant in influencing perceived changes in land-use and land-cover. The models explained between $4.8 \%$ $\left(\right.$ Cox \& Snell R $\left.{ }^{2}\right) \& 7.2 \%\left(\right.$ NagelkerkeR $\left.^{2}\right)$ and 7.2\% (Cox \& Snell R $\left.{ }^{2}\right) \& 11.7 \%\left(\right.$ NagelkerkeR $\left.^{2}\right)$ of the variance in land-cover status resulting from agricultural expansion and population growth respectively (Table 6). The two models correctly classified $75.8 \%$ and $81.5 \%$ of the cases each. 
Table 6: Factors influencing land-use land-cover change

\begin{tabular}{c|ccccc}
\hline Dependent variable & Chi-square $\left(\square^{2}\right)$ & $d f$ & Sig & Cox \& Snell R $^{2}$ & Nagelkerke $^{2}$ \\
\hline Charcoal production & 18.159 & 16 & 0.315 & 0.048 & 0.072 \\
Agricultural expansion & 28.077 & 16 & $0.031^{*}$ & 0.073 & 0.107 \\
Settlements & 11.018 & 16 & 0.808 & 0.029 & 0.079 \\
Population growth & 27.985 & 16 & $0.032^{*}$ & 0.072 & 0.117 \\
\hline
\end{tabular}

*Significant at 0.05 level of confidence

Table 7 shows that secondary education had a significant influence $(\mathrm{p}<0.020 ; \mathrm{p}<0.021)$ when engaging in charcoal production, expanding fields and also fostering population growth. In addition, household size was found to significantly influence agricultural expansion $(\mathrm{p}<0.003)$ and population growth $(\mathrm{p}<0.034)$.

Table 7: Socio-economic variables influencing land-use and land-cover change

\begin{tabular}{|c|c|c|c|c|c|c|c|c|c|}
\hline \multirow[t]{2}{*}{ Dependent } & \multirow[t]{2}{*}{ Independent variable } & \multirow[t]{2}{*}{ B } & \multirow[t]{2}{*}{ Std. Error } & \multirow[t]{2}{*}{ Wald } & \multirow[t]{2}{*}{ df } & \multirow[t]{2}{*}{ Sig. } & \multirow[t]{2}{*}{$\operatorname{Exp}(B)$} & \multicolumn{2}{|c|}{$\begin{array}{l}\text { 95\% Confidence Interval } \\
\text { for } \operatorname{Exp}(B)\end{array}$} \\
\hline & & & & & & & & Lower & Upper \\
\hline \multirow[t]{10}{*}{ Charcoal } & Gender & 0.513 & 0.282 & 3.315 & 1 & 0.069 & 1.671 & 0.961 & 2.904 \\
\hline & Age class & 0.005 & 0.165 & 0.001 & 1 & 0.976 & 1.005 & 0.727 & 1.388 \\
\hline & Education - Primary & 0.625 & 0.384 & 2.653 & 1 & 0.103 & 1.868 & 0.881 & 3.964 \\
\hline & Education - Secondary & 1.014 & 0.436 & 5.408 & 1 & $0.020 *$ & 2.757 & 1.173 & 6.481 \\
\hline & Education - Tertiary & 1.094 & 1.180 & 0.860 & 1 & 0.354 & 2.985 & 0.296 & 30.128 \\
\hline & Wealth category - Very rich & 0.571 & 0.577 & 0.982 & 1 & 0.322 & 1.771 & 0.572 & 5.482 \\
\hline & Wealth category - Rich & 0.098 & 0.380 & 0.067 & 1 & 0.796 & 1.103 & 0.524 & 2.325 \\
\hline & Wealth category - Poor & 0.419 & 0.316 & 1.758 & 1 & 0.185 & 1.520 & 0.818 & 2.824 \\
\hline & Household size class & -0.014 & 0.144 & 0.010 & 1 & 0.920 & 0.986 & 0.743 & 1.307 \\
\hline & Residence status & -0.009 & 0.257 & 0.001 & 1 & 0.972 & 0.991 & 0.599 & 1.641 \\
\hline \multirow{10}{*}{$\begin{array}{l}\text { Agriculture } \\
\text { expansion }\end{array}$} & Gender & 0.180 & 0.262 & 0.471 & 1 & 0.493 & 1.197 & 0.716 & 2.002 \\
\hline & Age class & 0.264 & 0.168 & 2.482 & 1 & 0.115 & 1.303 & 0.937 & 1.810 \\
\hline & Education - Primary & 1.006 & 0.520 & 3.741 & 1 & 0.053 & 2.736 & 0.987 & 7.586 \\
\hline & Education - Secondary & 1.258 & 0.546 & 5.307 & 1 & $0.021 *$ & 3.519 & 1.207 & 10.264 \\
\hline & Education - Tertiary & -18.586 & 0.000 & & 1 & & $8.477 \mathrm{E}-9$ & $8.477 \mathrm{E}-9$ & $8.477 \mathrm{E}-9$ \\
\hline & Wealth category - Very rich & -0.094 & 0.513 & 0.034 & 1 & 0.854 & 0.910 & 0.333 & 2.489 \\
\hline & Wealth category - Rich & -0.338 & 0.400 & 0.712 & 1 & 0.399 & 0.714 & 0.326 & 1.563 \\
\hline & Wealth category - Poor & -0.179 & 0.322 & 0.308 & 1 & 0.579 & 0.836 & 0.445 & 1.573 \\
\hline & Household size class & 0.404 & 0.134 & 9.033 & 1 & $0.003 *$ & 1.498 & 1.151 & 1.950 \\
\hline & Residence status & 0.133 & 0.251 & 0.279 & 1 & 0.597 & 1.142 & 0.698 & 1.868 \\
\hline \multirow[t]{6}{*}{ Settlements } & Gender & -0.645 & 0.530 & 1.482 & 1 & 0.223 & 0.525 & 0.186 & 1.482 \\
\hline & Age class & -0.272 & 0.294 & 0.859 & 1 & 0.354 & 0.762 & 0.428 & 1.355 \\
\hline & Education - Primary & 0.871 & 1.077 & 0.654 & 1 & 0.419 & 2.390 & 0.289 & 19.739 \\
\hline & Education - Secondary & 1.160 & 1.104 & 1.104 & 1 & 0.293 & 3.189 & 0.367 & 27.748 \\
\hline & Education - Tertiary & -16.616 & 0.000 & & 1 & & $6.080 \mathrm{E}-8$ & $6.080 \mathrm{E}-8$ & $6.080 \mathrm{E}-8$ \\
\hline & Wealth category - Very rich & -1.383 & 1.119 & 1.527 & 1 & 0.217 & 0.251 & 0.028 & 2.248 \\
\hline
\end{tabular}




\begin{tabular}{|l|l|c|c|c|c|c|c|c|c|}
\hline \multirow{5}{*}{} & Wealth category - Rich & -1.017 & 0.725 & 1.969 & 1 & 0.161 & 0.361 & 0.087 & 1.497 \\
\cline { 2 - 10 } & Wealth category - Poor & -0.438 & 0.506 & 0.751 & 1 & 0.386 & 0.645 & 0.239 & 1.738 \\
\cline { 2 - 10 } & Household size class & 0.142 & 0.249 & 0.326 & 1 & 0.568 & 1.153 & 0.708 & 1.876 \\
\cline { 2 - 9 } & Residence status & 0.076 & 0.442 & 0.030 & 1 & 0.863 & 1.079 & 0.454 & 2.566 \\
\hline \multirow{5}{*}{$\begin{array}{l}\text { Population } \\
\text { growth }\end{array}$} & Gender & 0.036 & 0.292 & 0.015 & 1 & 0.902 & 1.037 & 0.585 & 1.838 \\
\cline { 2 - 9 } & Age class & 0.178 & 0.183 & 0.947 & 1 & 0.331 & 1.195 & 0.835 & 1.710 \\
\cline { 2 - 9 } & {$[$ Education - Primary } & 0.675 & 0.574 & 1.383 & 1 & 0.240 & 1.963 & 0.638 & 6.043 \\
\cline { 2 - 9 } & {$[$ Education - Secondary } & 1.294 & 0.594 & 4.739 & 1 & $0.029 *$ & 3.646 & 1.138 & 11.686 \\
\cline { 2 - 9 } & [Education - Tertiary & 1.148 & 1.258 & 0.833 & 1 & 0.361 & 3.153 & 0.268 & 37.099 \\
\cline { 2 - 9 } & Wealth category - Very rich & -0.572 & 0.660 & 0.751 & 1 & 0.386 & 0.564 & 0.155 & 2.058 \\
\cline { 2 - 9 } & [Wealth category - Rich & -0.107 & 0.475 & 0.051 & 1 & 0.821 & 0.898 & 0.354 & 2.280 \\
\cline { 2 - 9 } & [Wealth category - Poor & 0.554 & 0.377 & 2.156 & 1 & 0.142 & 1.740 & 0.831 & 3.644 \\
\cline { 2 - 9 } & Household size class & 0.313 & 0.148 & 4.512 & 1 & $0.034 *$ & 1.368 & 1.025 & 1.827 \\
\cline { 2 - 9 } & Residence status & -0.055 & 0.279 & 0.039 & 1 & 0.843 & 0.946 & 0.548 & 1.634 \\
\hline
\end{tabular}

*Significant at 0.05 level of confidence

\section{Discussion}

\subsection{Demographic characteristics}

Our results indicate a higher average household size than most studies in the region. The larger the family size, the greater the potential for overall population growth of the area, growing number of people and higher population density. The high household size in our study areas may be attributed to a number of demographic factors such as: (a) belief in extended family systems; (b) traditional values and belief systems that consider large family as a source of labour force for cultivation as most families still use hand-hoeing farming methods and; (c) in-migration at village level. A study by Bongaarts (2001) revealed that overall average household size in rural sub-Saharan Africa is 5.3 persons. Similarly, Alelign et al. (2011), Teshome et al. (2015) and Zegeye et al. (2014) observed the average household size ranging from 5.6 to 7 in some parts of Ethiopia, while Giliba et al. (2011), Kalaba et al. (2013) and Kamwi et al. (2015) observed the average family size of 5.0 and 6.0 in the Bereku Forest Area of Tanzania, some parts of Copperbelt province of Zambia and the Zambezi region of Namibia, respectively.

Household size is an important indicator of the population's potential to impact on the environment. Our study revealed that household size had influence on collection and use of wild fruits and livestock fodder. Furthermore, the results showed significant association between household size and collection of construction poles, wild fruits and thatching grass. This is reinforced by existing research findings in Ethiopia (Mamo et al., 2007), Burkina Faso 
(Coulibaly-Lingani et al., 2009) and Uganda (Tugume et al., 2015) who observed a positive correlation between dependence on forest products and household size. This suggests that households with large families, especially those with limited income opportunities, are more dependent on forest resources to fulfil their basic needs (see Bhandari and Jianhua, 2017). A study by Ashraf et al (2017) indicated that demographic changes particularly population growth, its density and distribution greatly influence the quality of forests. Ashraf et al. further noted that a high share of rural populations living in poverty rural communities is significantly detrimental to forest cover and forest condition. Coulibaly-Lingani et al. (2009) asserted that individuals from large families may have difficulties in accessing alternative sources of subsistence and thus become inclined to use of forest resources.

Although large family size constitute a social burden in terms of basic livelihood needs, households with many members of productive and economically active age, use their available labour inputs to an advantage in farming and forest products exploitation. Logistic regression results indicated that household size was found to significantly influence agriculture expansion and population growth. These results reinforce existing research findings that as household size increases, demand for new agricultural land grows (Pan et al., 2007). This scenario creates greater potential for migration, land shortages and also an increase in rates of deforestation. Furthermore, the results show that as many of the individual household members reach adulthood, more demand for resources, income and decisions for more land for subsistence crop production arise, and in return affect LULC through forest clearing. Similarly, Haule (2014) also noted that with more members of the household within the age group of 20-45 years, the higher the likelihood of being involved in activities that cause or accelerate deforestation. Furthermore, a number of studies in other parts of the developing world namely Rwanda (Nduwamungu, 2001) and Tanzania (Madulu, 1996) observed a strong relationship between size of household and environmental degradation.

\subsection{Education level}

Education level of rural communities can influence households' dependence on forest products use (Timko et al., 2010; Bhandari and Jianhua, 2017). Analysis of educational levels in the two study sites revealed that a significant proportion of household members ended at primary and junior secondary school levels only. As such, levels of low education in the areas are high. 
This may underline the local communities' over dependence on forest products for livelihood due to limited capacity to seek employment opportunities in the formal sector. Higher education levels are associated with low dependence on forests for livelihoods and this is mainly because education provides a wider range of employment opportunities in other sectors of the economy (see Adhikari et al., 2004; Mamo et al., 2007; Tugume et al., 2015) and generally wider asset base (Timko et al., 2010). Furthermore, Coulibaly-Lingani et al. (2009) observed that education substantially influenced individuals' access to Non-Timber Forest Products (NTFPs). Our results indicate that there were significant levels of association between education level and use of products such as caterpillars, wild vegetables and collection of livestock fodder. Furthermore, our results revealed that education level was an important determinant capable of substantially influencing households' patterns of use of land and also population growth.

\subsection{Population distribution}

Ethnic diversity in rural areas is often strongly influenced by the medium and long-term demographic consequences of immigration. Our study revealed that even though the two areas were originally inhabited by Lamba speaking people, over the years, there has been a steady influx of other tribes mainly dominated by Bemba, Lala, Tonga and Lenje speaking groups respectively. Thus the majority of the interviewed household members had migrated into the study sites. The resulting consequences of such migration into a new area are high population densities and pressure on land. Our findings are in agreement with a study by Ashraf et al. (2017), who noted that demographic changes, particularly population growth, density and distribution have significant influence on quality and extent of forests. Furthermore, the increase in tribal groupings entail a rich cultural diversity and also varying land-use practices which in the long run influence LULC changes in the catchment areas. These findings are consistent with a study by Lacuna-Richman (2003) who observed that ethnic mix brings about a diversity of abilities, experiences, cultures which may be productive and may lead to innovation and creativity. This scenario provides an insight of the potential of migration forces in fostering population growth and influence of socio-cultural characteristics on LULC change.

Two forms of migration were noticed and these are rural-rural migration - mostly motivated by the rural people's search for new farmland, and urban-rural migration, mainly facilitated by tough living conditions necessitated by loss of jobs or retrenchments. Majority of participants 
that migrated cited loss of employments due to Structural Adjustment Programme (SAP) which the Zambian Government implemented between 1990 and 1995. Lall et al. (2006) and Haule, (2010), in their study of population dynamics noted that the choice to migrate involves circumstantial factors, i.e. "push factors" - that constitute the problems, limitations or adverse situations which force people to move out of a specific locality and also "pull factors" which attract migrants to areas of preference.

\subsection{Farming practices and production trends}

The main farming practices among farmers in the study area were crop rotation and shifting cultivation. However, it was observed that shifting cultivation was more predominant and this could mainly be attributed to local peoples' customs and tradition. By virtue of its dominance and taking short-term period of cultivation before clearing new areas, shifting cultivation has contributed to change in land-cover and overall forest ecosystems. This is corroborated by other studies (e.g. Luoga, 2000; Mwampamba, 2009) who noted that shifting cultivation alone contributes more than $50 \%$ of deforestation in Tanzania. Furthermore, effects of shifting cultivation on forest ecosystems are exuberated by high population densities.

The fact that production trends (in an area predominantly under traditional cultivation systems) for the main crop have shown low productivity signifies that communities have to look for sustenance from off-farm activities such as charcoal production, which causes changes in land-use and land-cover of forest ecosystems. Therefore, better methods of farming need to be explored. Notwithstanding, the cultivated land size for majority of households was too small to adequately satisfy basic household needs, especially with the low technology agriculture production in the study areas. The small size of cultivated land per household may be attributed to inadequate capital to purchase farm implements and agricultural inputs (see CSO, 2010). Mostly, households depend on hand tools such as hoes and axes to prepare and till their land. According to Arega et al., (2013) the use of such outdated production technologies characterizes most rural agricultural activities in rural Africa and makes it difficult to do much at household level. Most interviewed households indicated low yields for the main crop (i.e. maize) hence placing most of households in a relatively vulnerable situation. They attributed low yield to the following; lack agricultural inputs, labour and limited agricultural extension services. This may explain why most of the interviewed households indicated the production trends show low 
productivity across the two study areas. When agricultural activities fail to make households earn sufficient living from farm production alone, they look for supplementary non/off-farm income generating activities (Yizegaw et al., 2015). This may be the reason why the community in the

study areas have developed alternative livelihood strategies such as charcoal production, collection of wild fruits and mushroom for sale as a way of supplementing their failing agricultural activities.

\subsection{Household income and community forest resource utilisation}

Our study revealed that rural communities living around Miengwe and Katanino forests have a strong attachment to forest products and services. The long-term contribution of forest resources to household income and subsistence use of products has been widely acknowledged as noteworthy (Levang et al. 2005, Sunderlin et al. 2005; Rasmussen et al., 2017). For example, Shimizu (2006); Vedeld et al. (2007); Wunder et al. (2014) noted the safety-net role of forest resources in the lives of rural poor in improving livelihoods and quality of life. Similarly, Hickey et al. (2016) and Broegaard et al. (2017) indicate that in addition to agricultural crops, large proportions of rural populations continue to rely on forests and other habitats in order to secure adequate food and nutritionally balanced diets for their families. In our study, respondents noted that mushrooms, wild fruits and firewood were the most important and used subsistence forest products. Rural households' continued dependence on forest products for income generation implies that forest products form part of the income sources for the rural communities. Likewise, in Nigeria, Adetola and Adetoro (2014) show that local communities encroach into conservation areas to obtain forest products for sustenance and income generating activities. In this study, we observed that the choice of forest products is influenced by the product's potential as a source of income. The majority of the discussants indicated that charcoal production is the most reliable off-farm income-generating activity among the rural poor. For example, one female discussant had this to say:

"Charcoal sale in the city of Lusaka currently is a lucrative business venture as such it doesn't take long for it to be bought"

The major implication of this finding is that it demonstrates that charcoal production and sale is central to local communities' income base in the miombo eco-region (see CHAPOPSA, 2002). 
Therefore, the realisation of the importance of miombo woodlands to well-being of rural communities is key to integrating household needs and environmental security into sustainable forest management planning that is cognisant of incorporated disturbances such as charcoal production (see Syampungani, 2008).

The age of household head plays a significant role in determining income generating activities. Our study revealed significant levels of association between age and charcoal production, bush meat hunting and collection of brooms. Similar findings were noted by Kalaba et al (2013) who reported that labour-demanding activities such as charcoal production were more commonly practiced by young men. Wealth differentiation in the use of forest products was observed in the study areas. Households belonging to the "wealthier" income groups, especially the Tonga migrants, who are culturally cattle keepers extract and use the forests as a source of fodder for livestock. Similar studies by Kalaba et al. (2013), observed a significantly greater proportion of wealthy households using the forest for animal fodder. This association is likely due to the households' ability and capacity to purchase and rear animals mainly cattle.

\subsection{Local ecological knowledge and implications for forest conservation}

Religious beliefs, traditional beliefs, cultural values and practices have been known to play a crucial role for the successful conservation of the environment and specific organisms especially in the developing countries (Lingard et al., 2003). Considering the future scenarios that global warming presents, traditional knowledge systems, through cultural and religious belief system can significantly contribute to ecological recovery and hence a build-up of C stocks. Our study revealed that protection of burial sites was one of the highly-respected practices among communities. The communities never extract or collect forest products from burial sites and therefore, such areas are mostly intact (see Fig. 9). Traditional knowledge and practices have been observed to contribute positively to protection of forests not only in the Miombo woodlands (Luoga et al 2000) but many other African vegetation formations (Lingard et al., 2003; WWF. 2006). This respect and subsequent preservation of certain species indicates that some indigenous practices have a positive impact on forest conservation. Results of this study show that traditional ecological knowledge plays a critical role in resource management and hence the need for inclusion in long-term planning. According to Ngara and Mangizyo (2013), indigenous 
and local knowledge system is embedded in a context of values and social conventions, ethical principles, religious beliefs, ritual taboos, customs and other cultural practices among local community members, which if abrogated may result in bad omen. For example, Msuya and Kideghesho (2009) reported the positive impact of traditional practice on protection of medicinal plant species in burial sites. These social values and cultural norms regarding sacred places command high respect among many African societies (Saj et al., 2006) and hence the existing potential for contributing towards reduced forest degradation and mitigating effects of climate change.

\subsection{Community perception on cause of forest cover loss}

It has been noted that local community's perception is that forests cover has decreased in the study areas in the past 10 years. Overall, respondents ranked charcoal production as the most predominant cause of forest cover loss. This was followed by agriculture expansion and population increase. A number of factors such as ready market and poverty may have contributed to the dominance of charcoal production among other forest use practices. The influence of ready market on charcoal production has also been reported in Tanzania (see Luoga et al., 2000). The absence of other alternative sustainable energy sources is a major driver of charcoal production in the Southern African savanna (Gumbo et al., 2013). Additionally, land-use and land-cover are aggravated by the fact that rural households have to cope with both poverty and variability in agriculture and forestry sectors which are impacted by the changes in climate (Kamwi et al., 2015).

On the other hand, results from logistic regression analysis revealed that agriculture expansion and population growth were key determinants of perceived changes in land-use and land-cover. These findings are consistent with studies by Defries et al. (2010) and Kamwi et al. (2015), who noted that agriculture is the main causes of dwindling forest cover, mainly due to its high responsiveness to realities of life such as communities' everyday need for food and the desire to pursue this need against all odds. In this study, we observed that the real cause of forest cover loss is poverty, which permeates many rural households in the two study areas and is deeply rooted in the daily needs of the rural communities. Similar observations were made by Aung et al. (2012) and Miyamoto et al. (2014) who, reported that poverty levels are the principle variable influencing forest product extraction and cover change. 


\section{Conclusions and recommendations}

Our research has contributed to the wider body of knowledge on the role of forests in rural household income provision from sale of products and livelihood support through subsistence use of forest products. Our analysis therefore confirm that forests play a critical role in rural livelihoods. The results showed that use of forest products is associated with individual household characteristics. For example, among the eight variables examined, gender, age, education, wealth status, household size and residence status were found to be significant determinants in the use of various forest products. These findings underscore the need to critically understand the relationship between household socio-economic factors and local forest utilization attributes for better forest management, policy and decision-making processes. The major policy implication of our finding is that miombo woodland is an importance resource in supporting household needs of rural communities and that practices such as charcoal production cannot be stopped or excluded. On the other hand, logistic regression model showed that agriculture expansion and population growth were found to be significant determinants of changes in land-use and land-cover. Therefore, forest policies should promote the integration of these utilization practices in forest or woodland management. Additionally, any attempts to avert deforestation should consider addressing social and economic problems faced by local communities. The study also revealed that local ecological knowledge systems (cultural and religious belief systems) can significantly contribute to ecological recovery of forest ecosystems.

From this study, we make two key recommendations namely: (i) the interrelationships between socio-economic factors and local forest utilization attributes should be contextualised critically by defensible and quantitative data, if policy strategies on forest conservation are to provide for sustainable land-use and land-cover management; (ii) integrating household needs and environmental security into policy frameworks that provide for inclusion of various utilization practices such as charcoal production into sustainable forest management; (iii) integrating local ecological knowledge into strategic land use planning and policy formulation processes.

\section{Conflict of interest}

The authors declare no conflict of interest. 


\section{Acknowledgement}

The authors are grateful to the African Forest Forum, South African Forestry Company Limited (SAFCOL) and the University of Pretoria for funding the first author to undertake this study. Additionally, National Science and Technology Council, through Zambia-Mozambique bilateral Agreement has also funded fieldwork. Special thanks go to the following people: Nalukui Matakala, Mulako Muimui, Cassius Mweele, Joseph Chikasha, Dimus Change, Lutangu Kalubi, Alice Mukuka, Chrispin Masanduko and Louis Sikalumbi for assisting in data collection. Gratitude also go to Benson Kabungo for his assistance with map development and other GIS/Remote Sensing related works. We owe much gratitude to Chief Nkambo (Late) and the farmers surrounding Miengwe and Katanino forest reserves for their hospitality and agreeing to the interviews. We thank the special issue editors and the two anonymous reviewers for their constructive critique and suggestion on the manuscript.

\section{References}

Adetola, B.O., Adetoro, A.C., 2014. Threats to biodiversity conservation in cross River National Park, Nigeria. Int. J. Conserv. Sci. 5(4), 547-552.

Adhikari, B., Di Falco, S. D., Lovett, J. C., 2004. Household characteristics and forest dependency: evidence from common property forest management in Nepal. Ecol. Econ. 48 (2), 245-257.

Alelign, A., Yemshaw, Y., Teketay, D., Edwards, S., 2011. Socio-economic factors affecting sustainable utilization of woody species in Zegie Peninsula, north-western Ethiopia. Trop. Ecol. 52(1), 13-24.

Angelsen, A., Jagger, P., Babigumira, R., Belcher, B., Hogarth, N. J., Bauch, S., Borner, J., Smith-Hall, C., Wunder, S., 2014. Environmental Income and Rural Livelihoods: A Global-Comparative Analysis. World Dev. 64(S1), S12-S28. DOI: 10.1016/j.worlddev.2014.03.006

Arega, B., Woldeamlak, B., Melanie, N., 2013. Rural households' livelihood assets, strategies and outcomes in drought-prone areas of the Amhara Region, Ethiopia: Case Study in Lay Gaint District. Afr. J. Agric. Res. 8 (46),5716-5727.

Ariti, A.T., van Vliet, J., Verburg, P.H. 2015. Land-use and land-cover changes in the Central Rift Valley of Ethiopia: Assessment of perception and adaptation of stakeholders. Appl. Geogr. 65, 28-37.

Ashraf, J., Pandey, R., de Jong, W. 2017. Assessment of biophysical, social and economic drivers for forest transition in Asia-Pacific region. For. Policy Econ. 76,35-44 
Aung, P. S., Pretzsch, J., Peter, R., 2012. Understanding forest dependency and resource extraction of local communities living around the protected area in Myanmar, Unpublished MSc Thesis, Dresden University of Technology, Dresden, German.

Austin, K.G., Mosnier, A., Pirker, J., McCallum, I., Fritz, S., Kasibhatla, P.S. 2017. Shifting patterns of oil palm driven deforestation in Indonesia and impolcations for zerodeforestation commitments. Land Use Policy 69, 41-48.

Babbie, E., \& Mouton, J., 2014. The practice of social research, (South African edition), Oxford University Press, Southern Africa.

Babulo, B., Muys, B., Nega, F., Tollens, E., Nyssen, J., Deckers, J., Mathijs, E., 2008. Household livelihood strategies and forest dependence in the highlands of Tigray, Northern Ethiopia. Agr. Syst. Vo. 98 (2),147-155.

Balama C., SuzanaAugustino, S., Eriksen, S., Makonda, F. B. S., 2016. Forest adjacent households' voices on their perceptions and adaptation strategies to climate change in Kilombero District, Tanzania. SpringerPlus 5: 792

Barribeau, P., Butler, B., Corney, J., Doney, M., Gault, J., Gordon, J., Fetzer, R., Klein, A., Rogers, C. A, Stein, I. F, Steiner, C., Urschel, H., Wagoner, T., Palmquist, M., 2015. Survey research, Colorado State University, USA. https://writing.colostate.edu/guides/pdfs/guide68.pdf. Accessed on 19/3/2017

Berkes, F., Folke, C (eds).,1998. Linking social and ecological systems: management practices and social mechanisms for building resilience. Cambridge University Press, Cambridge, UK.

Bhandari, D., Jianhua, Z. 2017. Household dependency on buffer zone community forest and its implication for management of Chitwan National Park, Nepal. Int. J. Sci. Vol. 6 (3).

Boissiere, M., Beaudoin, G., Hofstee, C., Rafanoharana, S. 2014. Participating in REDD+ Measurement, Reporting, and Verification (PMRV): Opportunities for Local People? Forests, 5,1855-1878, doi:10.3390/f5081855.

Bong, I.W., Felker, M.E., Maryudi, A. 2016. How Are Local People Driving and Affected by Forest Cover Change? Opportunities for Local Participation in REDD+ Measurement, Reporting and Verification. PLoS ONE 11(11): e0145330. doi:10.1371/journal.pone. 0145330

Bongaart, J., 2001. Household size and composition in the developing world. Policy Research Division working paper \# 144.

Broegaard, R.B., Rasmussen, L.V., Dawson, N., Mertz, O., Vongvisouk, T., Grogan, K., 2017. Wild food collection and nutrition under commercial agriculture expansionin agricultureforest landscapes. For. Policy Econ. 84, 92-101.

Brown, D. G., Verburg, P. H., Pontius Jr., R. G., Lange, M. D. 2013. Opportunities to improve impact, integration, and evaluation of land change models. Curr. Opin. Env. Sust. 5, 452457.

Campbell B. M., Vermeulen S. J., Lynam T. J. P., 1991. Value of trees in the small-farming sector of Zimbabwe. International Development Research Centre, Ottawa. 
Campbell, B. M., 1996. The Miombo in Transition: Woodlands and Welfare in Africa. Bogor, Indonesia: CIFOR.

Central Statistical Office (CSO)., 2010. Living conditions monitoring survey report 2006 \& 2010. Living Conditions Monitoring branch, Central Statistical Office, Lusaka.

CHAPOPSA. 2002. Charcoal potential in Southern Africa. INCO_DEV: International cooperation with developing countries (1998-2002). https://www.sei.org/publications/charcoal-potential-southern-africal Contract number: ERBIC18CT980278 FINAL REPORT, 2002.

Coulibaly-Lingani, P., Tigabu, M., Savadogo, P., Oden, P. C., Quadba, J. M., 2009. Determinants of access to forest products in southern Burkina Faso. For. Policy Econ. 11, $516-524$

CSO. 2010. Zambia 2010 Census of population and housing: Report on characteristics of households and housing. CSO, Lusaka, Zambia.

Defries, R., Pandey, D. 2010. Urbanisation, the energy ladder and forest transitions in India's emerging economy. Land Use Policy 27(2), 130-138.

Defries, R.S., Rudel, T., Uriarte, M., Hansen, M., 2010. Deforestation driven by urban population growth and agricultural trade in the twenty-first century. Natl. Geosci. 3,178181

FAO. 2010. A system of integrated agricultural censuses and surveys. Italy: World Programme for the Census of Agriculture.

Giliba, R.A., Boon, E.K., Kayombo, C.J., Chirenje, L.I., Musamba, E.B., 2011. The influence of socio-economic factors on deforestation: A case study of the Bereku Forest Reserve in Tanzania. J. Biodiv. 2 (1), 31-39.

Gumbo, D.J., Moombe, K.B., Kandulu, M.M., Kabwe, G., Ojanen, M., Ndhlovu, E., Sunderland, T.C.H., 2013. Dynamics of the charcoal and indigenous timber trade in Zambia: A scoping study in Eastern, Northern and North-western provinces. Occasional Paper 86. CIFOR, Bogor, Indonesia.

Halue, M.J.M., 2010. Population dynamics and sustainable forest conservation: A case study of the West Matogoro catchment area in Songea, Tanzania. Unpublished $\mathrm{PhD}$ thesis, University of KwaZulu-Natal.

Haule, J.M. 2014. Population, Development and deforestation in Songea District, Tanzania. Nat. Resourc. 5, 15-24.

Hickey, G.M., Poiliot, M., Smith-Hall, C., Wunder, S., Nielsen, M.R., 2016. Quantifying the economic contribution of wild food harvests to rural livelihoods: a global-comparative analysis. Food Policy 62, 122-132.

Hsieh, H., Shannon, S.E. 2005. Three approaches to qualitative content analysis. Qual. Health Res. 15(9), 1277-1288.

IBM Corp. Released 2015. IBM SPSS Statistics for Windows, Version 23.0. Armonk, NY: IBM Corp 
Ickowitz, A., Powell, B., Salim, M.A., Sunderland, T.C.H., 2014. Dietary quality and tree cover in Africa. Glob. Environ. Chang. 24, 287-294.

Integrated Land Use Assessment (ILUA). 2017. Integrated Land Use Assessment Phase II Report for Zambia. The Food and Agriculture Organization of the United Nations and the Forestry Department, Ministry of Lands and Natural Resources, Lusaka, Zambia.

Kalaba, F. K., 2005. The role of indigenous fruit trees in the rural livelihood: A case of Mwekera, Copperbelt Province, Zambia. MSc. Thesis, University of Stellenbosch.

Kalaba, F.K., Quinn, C.H., Dougill, A.J., 2013. Contribution of forest provisioning ecosystem services to rural livelihoods in the Miombo woodlands of Zambia. Popul. Environ. 35, 159 -182 .

Kamwi, J.M., Chirwa, P.W.C., Manda, S.O.M., Graz. P.F., Katsch, C., 2015. Livelihoods, landuse and land-cover change in the Zambezi region, Namibia. Popul. Environ. DOI 10.1007/s11111-015-0239-2.

Lacuna-Richman, C., 2003. Ethnicity and the utilization of non-wood forest products: fi ndings from three Philippine villages. Silva Fennica 37(1), 129-148.

Lall, S.V., Selod, H., Shalizi, Z., 2006. Rural-Urban migration in developing countries: A survey of theoretical predictions and empirical findings. World Bank Policy Research paper 3915.Washington DC 20433, USA.

Lambin, E.F., Geist, H.J., Lepers, E., 2003. Dynamics of Land-Use and Land-Cover Change in Tropical regions. Annu. Rev. Env. Resour. 28,205-41.

Levang, P., Dounias, E., Sitorus, S., 2005. Out of the forest, out of poverty? For. Trees and Liveli. 15, 211-235.

Lingard, M., Raharison, N., Rabakonandrianina, E., Rakotoarisoa J.A., Elmqvist, T., 2003. The role of local taboos in conservation and management of species: The radiated tortoise in southern Madagascar. Conserv. Soc. 1, 223-246.

Luoga, E.J., Witkowski, E.T.F., Balkwill, K., 2000. Differential utilization and ethnobotany of trees in Kitulanghalo forest reserve and surrounding communal lands, eastern Tanzania. Econ. Bot. 54(3) pp, 328-343.

Luoga, E.J. 2000. Subsistence use of wood products and shifting cultivation within miombo woodland of eastern Tanzania, with special note on commercial uses. S. Afr. J. Bot. 66,7285

Luoga, E.J., Witkowski, E.T.F., Balkwill, K., 2000. Economics of charcoal production in miombo woodlands of eastern Tanzania: some hidden costs associated with commercialisation of the resources. Ecol. Econ. 35, 243-257.

Madulu, N.F., 1996. Environmental degradation and marital fertility changes in Tanzania: The Case of Kondoa District, Unpublished PhD Thesis, University of Dar es Salaam.

Madulu, N.F., 2001. Population Dynamics Sustainable Conservation of Protected Areas in Tanzania: The Case of Swagaswaga Game Reserve in Kondoa District, READ No. 2, Report in Environmental Assessment and Development, Applied Environmental Impact Assessment, Uppsala University, Sweden. 
Mamo, G., Sjaastad, E., Vedeld, P., 2007. Economic dependence on forest resources: a case from Dendi District, Ethiopia. For. Policy Econ. 9, 916-927.

Martinez, S., Mollicone, D., 2012. From land-cover to land-use: a methodology to assess landuse from remote sensing data. Remote Sens_Basel, 4,1024-1045.

Maryudi, A., Sahinde, M.A.K. 2017. Research trends: Power analysis in polycentric and multilevel forest governance. Forest Policy and Economics 81:65-68.

Mitinje E, Kessy J.F, Mombo F., 2007. Socio-economic factors influencing deforestation on the Uluguru Mountains. Discov. Innovat. 19, 139.

Miyamoto, M., Parid, M.M., Aini, Z.N., Michinaka, T., 2014. Proximate and underlying causes of forest cover change in Peninsular Malaysia. For. Policy Econ. 44, 18-25.

Morgan, D.L. 1996. Focus groups. Annu. Rev. Soc. Vol. 22,129-152.

Msuya, T.S., Kidegesho, J.R., Mosha, T.C.E., 2010. Availability, preference and consumption of indigenous foods in the Eastern Arc Mountains, Tanzania. Ecol. Food Nutr. 49,208-227

Msuya, T.S., Kideghesho, J.R., 2009. The role of traditional management practices in enhancing sustainable use and conservation of medicinal plants in West Usambara Mountains, Tanzania. Trop. Conserv. Sci. Vol.2 (1), 88-105. Accessed from: www.tropicalconservationscience.org. [Accessed no: 8/3/2017]

Mukherjee, N., 1992. Villagers' perception of rural poverty through the mapping methods of PRA. In Rapid Rural Appraisal Notes Number 15. Special Issue on Applications of Wealth Ranking, London International Institute for Environment and Development.

Mwampamba, H.T. 2009. Forest recovery and carbon sequestration under shifting cultication in the eastern Arc Mountain, Tanzania: Landscape and land-use effects. Unpublished desertation submitted in partial satisfaction of the requirements for the degree of Doctor of Philosophy in Ecology in the office of graduate studies of the University of California $183 p$.

Nduwamungu, J., 2001. Dynamics of deforestation in Miombo woodlands: The case of Kilosa District, Tanzania. Unpublished PhD thesis. Sokoine University of Agriculture, Tanzania.

Ngara, R., Mangizyo, R.V., 2013. Indigenous knowledge systems and the conservation of natural resources in the shangwe community in Gokwe District, Zimbabwe. Int. J. Asian Social Sci. 3 (1), 20-28

Njovu, P., Chuzu, P., Nguvulu, C.Z., 2004. Key threats and opportunities for conservation of biological and natural resources in the Copperbelt areas of biological significance. Analytical report, WWF-SARPO.

Nurrochmat, D.R., Nugroho, I.A., Hardjanto., Purwadianto, A., Maryudi, A., Erbaugh, J.T. 2017. Shifting contestation into cooperation: Strategy to incorporate different interest of actors in medicinal plants in Meru Betiri National Park, Indonesia. For. Policy Econ. 83,162-168

Nzunda, N.G., Munishi, P.K.T., Soka, G.E., Monjare, J.F. 2013. Influence of socio-economic factors on land-use and vegetation cover changes inand around Kagoma Forest Reserve in Tanzania. Ethoip. J. Env. Studies Manag. Vol. 6(5), 480-488. 
Obua J., Banana, A.Y., Turyahabwe, N., 1998. Attitudes of local communities towards forest management practices in Uganda: the case of Budongo forest reserve. Commonw Forest Rev. 77(2), 113-118.

Pallant, J. 2014. SPSS Survival Manual: A step by step guide to data analysis using SPSS for Windows (version 10). Open University press, Buckingham, Philadelphia.

Pan, W., Carr, D., Barbierri, A., Bilsborrow, R., Suchindran, C. 2007. Forest Clearing in the Ecuadorian Amazon: A Study of Patterns over Space and Time. Popul. Res. Policy Rev. 26,635-659.

Peng, C.Y.J., Lee, K.L., Ingersoll, G.M., 2002. An introduction to logistic regression analysis and reporting. J. Educ. Res. 96 (1), 3-14.

Powell, B., Ickowitz, A., Mcmullin, S., Jamnadass, R., Padoch, C., Pinedo-Vasque, M., Sunderland, T., 2013. The role of forests, trees and wild biodiversity for nutrition-sensitive food systems and landscapes. In: Expert Background paper for the International Conference on Nutrition (ICN 2). FAO Rome.

Powell, B., Thilsted, S., Ickowitz, A., Termote, C., Sunderland, T., Herforth, A., 2015. Improving diets with wild and cultivated biodiversity from across the landscape. Food Sec. 7(3), 535-554.

Rahman, M.S., Sarker, P.K., Sadath, M.N., Giessen, L., 2018. Policy changes resulting in power changes? Quantitative evidence from 25 years of forest policy development in Bangladesh. Land Use Policy, 70,419-431

Rasmussen, L.V., Watkins, C., Agrawal, A., 2017. Forest contribution to livelihoods in changing agriculture-forest landscapes. For. Policy Econ. 84, 1-8.

Richards, M., Kanel, K., Maharjan, M., Davies, J., 1999. Towards participatory economic analysis by forest user groups in Nepal. Overseas Development Institute in collaboration with the Nepal-UK Community Forestry Project, London. (Accessed from: https://www.odi.org/sites/odi.org.uk/files/odi-assets/publications-opinion-files/6139.pdf [Accessed on 6/3/2017]

Saj, T.L., Mather, C., Sicotte. P., 2006. Traditional taboos in biological conservation: the case of Colobus vellerosus at the Boabeng-Fiema Monkey Sanctuary, Central Ghana. Soc. Sci. Inform. 45(2), 285-310

Schwartz, M.W., Caro, T.M., 2003. Effect of selective logging on trees and understory regeneration in miombo woodlands. Afr. J. Ecol. 41, 75-82.

Shackleton, S., Paumgarten, F., Kassa, H., Husselman, M., Zida, M., 2011. Opportunities for enhancing poor women's economic empowerment in the value chains of three African nontimber forest products (NTFPs). Int. Forest. Rev. 13(2), 136-151.

Shimizu, T., 2006. Assessing the access to forest resources for improving livelihoods in West and Central Asia countries. Livelihoods Support Programme. LSP Working Paper 33. Food and Agriculture Organisation of the United Nations, FAO, Rome. p. 42.

Singh, A.S., Masuku, M.B., 2014. Sampling techniques and determination of sample size in applied statistics research: an overview. Int. J. Econ. Comm. Manag. Vol. II, Issue 11. 
Somorin, O.A., 2010. Climate impacts, forest-dependent rural livelihoods and adaptation strategies in Africa: A review. Afr. J. Environ. Sci. Techn. Vol. 4(13), pp. 903-912.

Sunderland, T., Abdoulaye, R., Ahammad, R., Asaha, S., Baudron, F., Deakin, E., Duriaux., J.Y., Eddy, I., Foli, S., Gumbo D., Khatun, K., Kondwani, M., Kshatriya, M., Leonald, L., Rowland, D., Stacey, N., Tomscha, S., Yang, K., Gergel, S., Vianen, J.V. 2017. A methodological approach for assessing cross-site landscape change: Understanding socioecological systems. For. Policy Econ. 84, 83-91

Sunderland, T., Achdiawan, R., Angelsen, A., Babigumira, R., Ickowitz, A., Paumgarten, F., Reyes-Garcia, V., Shively, G., 2014. Challenging Perceptions about Men, Women, and Forest Product Use: A Global Comparative Study. World Dev. http://dx.doi.org/10.1016/j.worlddev.2014.03.003

Sunderlin W.D., Angelsen, A., Belcher, B.., Burgers, P., Nasi, R., Santoso, L., Wunder, S., 2005. Livelihoods, forests, and conservation in developing countries: an overview. World Dev. 33(9), 1383-1402.

Sunderlin, W.D., Angelsen, A., Wunder, S., 2004. Forests and Poverty alleviation. Centre for International Forestry Research (CIFOR).

Susanti, A., Maryudi, A. 2016. Development narratives, notions of forest crisis, and boom of oil palm plantations in Indonesia. For. Policy Econ. 73, 130-139

Syampungani, S. 2008. Vegetation Change Analysis and Ecological Recovery of the CopperbeltMiombo woodlands of Zambia. PhD Thesis, University of Stellenbosch, RSA.

Teshome, B., Kassa, H., Mohammed, Z., Padoch, C., 2015. Contribution of dry forest products to household income and determinants of forest income levels in the Northwestern and Southern Lowlands of Ethiopia. Natural Resources 6: 331-338.

Timberlake, J., Chidumayo, E., 2001. Miombo ecoregion report. Occassional Publications in Biodiversity No. 20. WWF-SARPO, Biodiversity Foundation for Africa, Bulawayo, Zimbabwe. [Accessed from: http://www.biodiversityfoundation.org/documents/BFA\%20No.20_Miombo\%20Ecoregion \%20Vision\%20report.pdf[ Accessed on 5/3/2017]

Timko, J.A., Waeber, P.O., Kozak, R.A., 2010. The socio-economic contribution of non-timber forest products to rural livelihoods in Sub-Saharan Africa: knowledge gaps and new directions. Int. Forest. Rev. Vol. 12(3), $284-289$.

Tiwari, M.K., Saxena, A., 2011. Change detection of land-use/landcover pattern in and around Mandideep and Obedullaganj area using remote sensing and GIS. Int. J. Techn. Eng. Syst. 2(3).

Tugume, P., Buyinza, M., Namaalwa, J., Kakudidi, E.K., Mucunguzi, P., Kalema, J., Kamatenesi, M., 2015. Socio-economic predictors of dependence on non-timber forest products: lessons from Mabira Central Forest Researve communities. J. Agr. Environ. Sci. Vol. 4 (2), 195-214.

Turner II, B.L., Skole, D., Sanderson, S., Fischer, G., Fresco, L., Leemans, R.,1995. Land-Use and Land-Cover Change Science/Research Plan; IGBP Global Change Report No. 35 and HDPReport No. 7; International Geosphere-Biosphere Programme and the Human 
Dimensions of Global Environmental Change Programme: Stockholm, Sweden and Geneva, Switzerland.

Umar, B.B., 2014. A critical review and re-assessment of theories of smallholder decisionmaking: a case of conservation agriculture households, Zambia. In: Renewable Agriculture and Food Systems. 29. Cambridge University Press, pp. 277-290. https://doi.org/10.1017/S1742170513000148.

Ungirwalu, A., Awang, S.A., Suryanto, P., Maryudi, A., 2017. The ethno-techno-conservation approach in the utilization of Black Fruit (Haplolobus sp.) by the Wandamen people of Papua, Indonesia. Biodiversitas 18: 1336-1343.

Vedeld, P., Angelsen, A., Bojo, J., Sjaastad, F., Berg, G., 2007. Forest environmental income and the rural poor. For. Policy Econ. 9(7), 869-879.

Verbist, B., Putra, A.E.D., Budidarsono, S., 2005. Factors driving Land-use Change: Effects on watershed functions in a coffee Agroforestry System in Lampung, Sumatra. Agr. Syst. 85, 254-270

Vu, Q.M., Le, Q.B., Frossard, E., Vlek, P.L.G. 2014. Socio-economic and biophysical determinants of land degradation in Vietnam: An integrated causal analysis at the national level. Land Use Policy 36, 605-617.

Wunder, S., Borner, J., Shively, G., Wyman, M., 2014. Safety nets, gap filling and forests: a global-comparative perspective. World Dev. 64, S29-S42.

WWF (World-Wide Fund for Nature). 2006. WWF - Environmental \& conservation news: Africa. www.panda.org/about_wwf/where_we_work/africa/news. Accessed on

Yizegaw, Y.S., Okoyo, E.N., Beyene, F., 2015. Determinants of livelihood diversification strategies: The case of smallholder rural farm households in Debre Elias Woreda, East Gojjam Zone, Ethiopea. Afr. J. Agric. Res. Vol. 10(19),1998-2013

Yohannes W.A., Cotter., M., Kelboro G., Dessalegn W., 2018. Land Use and Land Cover Changes and their effects on the Landscape of Abaya-Chamo Basin, Southern Ethiopia. Land 7, 2; doi:10.3390/land7010002. 